WIDER Working Paper 2020/78

\title{
Unequal expectations
}

Gender inequality in the salary expectations of university students

Carlos Gradín, Felix Mambo, Yonesse Paris, and Ricardo Santos*

June 2020 
Abstract: Students' expectations about their future wages are established in the literature as relevant determinants of the choices made for education progression and, at the university level, for the area and course to be studied. In this paper, the first comparable analysis in sub-Saharan Africa, we examine the evidence and causes of unequal wage expectations of Mozambican university students prior to their transition to the labour market. The measurements of segmentation, stratification, and inequality decomposition are applied to better understand the underlying causes of these. They uncover a strong suggestion of anticipated labour market genderbased discrimination among high-skilled workers in Mozambique, as they prepare to transition from school to work.

Key words: inequality decomposition, segmentation, stratification, sub-Saharan Africa, wage expectations

JEL classification: D63, J24, J31, J71

*UNU-WIDER, Helsinki, Finland; corresponding author: santos@wider.unu.edu

This study has been prepared within the project on Inclusive growth in Mozambique-scaling-up research and capacity implemented in collaboration between UNU-WIDER, University of Copenhagen, University Eduardo Mondlane, and the Mozambican Ministry of Economics and Finance. The project is financed through specific programme contributions by the governments of Denmark, Finland, and Norway.

Copyright (C) UNU-WIDER 2020

Information and requests: publications@wider.unu.edu

ISSN 1798-7237 ISBN 978-92-9256-835-1

https://doi.org/10.35188/UNU-WIDER/2020/835-1

Typescript prepared by Lesley Ellen.

The United Nations University World Institute for Development Economics Research provides economic analysis and policy advice with the aim of promoting sustainable and equitable development. The Institute began operations in 1985 in Helsinki, Finland, as the first research and training centre of the United Nations University. Today it is a unique blend of think tank, research institute, and UN agency — providing a range of services from policy advice to governments as well as freely available original research.

The Institute is funded through income from an endowment fund with additional contributions to its work programme from Finland, Sweden, and the United Kingdom as well as earmarked contributions for specific projects from a variety of donors.

Katajanokanlaituri 6 B, 00160 Helsinki, Finland

The views expressed in this paper are those of the author(s), and do not necessarily reflect the views of the Institute or the United Nations University, nor the programme/project donors. 
The income and returns expected from education are seen by labour economics as a major incentive for educational achievement. Despite this, there is insufficient empirical knowledge about expectations and how they are constructed (Brunello et al. 2004), and, as yet, little is known about how individuals form wage expectations (Khosrozadeh et al. 2013; Manski 1993).

An increasing body of literature strongly suggests a gender gap in the wages expected by university students. The average expected wage gap, whether given by conditional estimates or sample statistics, ranges from almost 10 per cent to over 20 per cent (reaching 50 per cent in some cases), with different gaps within different areas of study. As we review below, the suggestion is that not only is a gender wage gap expected by university students, their expectation is consistent with the observed wage gaps.

While the body of literature on the gender gap in wage expectation is increasing, it refers almost entirely to high-income countries. This study is the first comparable analysis of the gender gap in university students' expected wages that has been applied to a low-income country. It aims to investigate the magnitude and nature of gender imbalances in the wages expected by final-year college students in Mozambique.

Mozambique is a low-income country in sub-Saharan Africa, characterized by a large subsistence agricultural sector and with a substantial gender gap in employment out of the subsistence sector, which has widened over time due to the lower level of female human capital and the lower conditional employment probabilities of married women as compared with men (Gradín and Tarp 2019). Only a small proportion of the population is able to get a college degree in Mozambique, but this share is expected to keep growing over time and has already been seen to play an important role in explaining the recent rise in inequality in the country because it increasingly accrues a disproportional share of total consumption (Gradín 2020a; Gradín and Tarp 2019). In our analysis, we follow recent developments in the literature on gender segregation, stratification, and wage gaps (Gradín 2020b; Firpo et al. 2009), and take advantage of a recent rich survey on the schoolto-work transitions of university graduates in the main universities in the country (S2WMozUni 2018a).

When asking senior college students about their expected wages and preferred sector of activity in their first year of work, important inequalities by gender emerge. Men and women expect to work in different sectors of activity and women expect a lower wage than men. Understanding this gender gap is key, as the lower wage expectations of women at the beginning of their careers may prevent them from negotiating better wages, leading them to lower entry-level wages than men. However, they can also be the result of rational expectations, in which women anticipate some sort of sex discrimination in the labour market.

The strong and differential selection of women and men into college implies that they may have different family and personal backgrounds. The fact that they pursue different fields of study further differentially constrains their opportunities in the labour market. In this paper, we take advantage of the rich information provided by students in the survey to investigate the extent to which these asymmetries in personal and family backgrounds help to shape gender differences in terms of work categories (that is, field of study and expected sectors of activity), as well as in terms of their expected wages. 
The paper firstly investigates whether men and women in college expect to work in the same work categories, which we define based on the area of study and expected sector of activity. Our results document the important extent of the segregation of men and women into these different work categories. About 24 per cent of men (or women) would have to change their respective categories to fully eliminate segregation. The paper then analyses whether the differences identified lead one gender to be more represented in areas of study and economic sectors that, on average, are expected to pay lower wages (gender-based stratification). We also document that these work categories are partially stratified by gender, because women tend to be over-represented in lower expected wage areas of study, with their preferred sector mitigating the effect of their area of study (they are over-represented in sectors with intermediate levels of expected wages). The level of segregation by gender cannot be explained by the different characteristics women and men take into the labour market, although they largely explain why women are over-represented in work categories with lower expected wages.

Secondly, the paper investigates the wages expected during the first year of work. Not surprisingly, women tend to expect wages that are about 17 per cent lower than those expected by men. The rich set of characteristics we consider (a wide variety of personal and family traits, including family background or results of cognitive tests that are typically omitted in studies of this kind) only explain a fifth of the expected gender wage gap, and mainly for those above the respective median. The relevant characteristics are shown to be the gender differences in the field of study and the lower proportion of women who are granted a scholarship or have to relocate to attend university. This means that the remaining differential (about 13 percentage point-differential) arises because the expected returns to those characteristics differ by gender. This may be the result of anticipated discrimination or different formation of expectations (such as different ability to predict real wages).

In the next section, we discuss what the literature informs us about the empirical evidence of gender gaps in wage expectations and their possible drivers. Section 3 presents the data, section 4 presents the methodology, and section 5 discusses the results of our study.

\section{$2 \quad$ Framing and measuring the gender gap in expected wages}

The first attempts to explain why women might expect a lower wage than men were by Mincer and Polachek (1974) and Polachek $(1975,1981)$. They sought to use human capital theory to justify gender-based inequality in wages. The suggestion was that women were less committed in the labour market, less willing to devote the same number of hours to work, and more prone to suspend work than men. Polachek $(1975,1981)$ then suggested, as justification for actual and expected wage gaps, the expectation of work interruptions due to pregnancy and family responsibilities. That hypothesis was invalidated by studies such as Blau and Ferber (1991) or Kiessling et al. (2019), which found a gap in expected wages even among women who did not expect to interrupt their careers.

If the originally proposed rationale has been proven to be insufficient to explain unequal wage expectations along gender identities, a partial answer may lie in the sources of information students rely on to build their wage expectations (Hyman 1942). The most obvious source of information is the family. Its economic status determines the quality of this information, with students who are unable to obtain good information tending towards a pessimistic stance (Ruder and Van Noy 2017). Furthermore, as suggested by Filippin and Ichino (2005), citing Breen and García-Peñalosa (2002), students are likely to seek information from their corresponding parents, i.e. male students from their fathers and female students from their mothers. More generally, students may look for 
role models from their own gender in the labour market. Female students are more likely to refer to women's occupations and average observed wages, while male students will refer to men's occupations and average observed wages (Heckert et al. 2002; Major and Konar 1984).

This links to a body of literature, cited by Bonnard and Giret (2016), which recommends looking beyond human capital theory and acknowledging that the labour market is constructed not only by economic rules but also by rules of power, dependence, and interdependence (Ferber and Nelson 2009). These rules may lead to gender-based market segmentation (Bergmann 1974; England and Folbre 2010), which may suggest the prevalence of a sort of 'pipeline' (Mariani 2008)_female students expect to follow, as if through a pipeline, choosing female-dominated university courses and joining female-dominated occupations, and, therefore, obtaining the respective wages. This seems to be confirmed by Hogue et al. (2010), Osikominu and Pfeifer (2018) and Kiessling et al. (2019), who found much of the gap in expected wages to be related to academic and occupational sorting patterns. This would suggest that the way ahead should be to promote women's participation in male-dominated occupations.

This may not be the full story, however. The 'pipeline theory' was tested in Canada by Schweitzer et al. (2011), who found that even when women expect to join a male-dominated occupation, their expected wage gap remains high. A similar result was obtained by Osikominu and Pfeifer (2018), who found a higher gender gap in the expected wages of students of (male-dominated) STEM ${ }^{1}$ degrees than of (relatively female-dominated) non-STEM degrees. This suggests that the gap in expected wages is not only driven by unequal choices of degrees or unequal expectations of future occupation, but also by unequal wage expectations in similar expected occupations. If anything, the 'pipeline theory' seems to be confirmed by an expectation of a higher wage gap in maledominated occupations and a lower one in female-dominated ones. Major and Konar (1984) and Filippin and Ichino (2005) found confirming evidence which suggests that even if they choose the same sectors, males and females are assigned different roles which award different wages that sustain or even increase the wage gap as their career progresses.

There may also be some socio-psychological factors at play. ${ }^{2}$ Men appear to be more likely to selfenhance, i.e. they tend to overestimate their future wages when comparing with their peers, while women do not (Smith and Powell 1990). Nevertheless, as Bonnard and Giret (2016) highlighted, referring to Jerrim (2011) and Orazem et al. (2003), while overestimation of future wages may be a positive incentive for putting more effort into education and job searching, relative underestimation may have the opposite effect. This is confirmed by Reuben et al. (2017) who found a consistent link between overconfidence (underconfidence), preference for higher (lower) pay occupations and more (less) aggressive wage negotiation. Zafar (2013), however, found no evidence of a link between confidence and self-esteem and a gender wage gap.

\footnotetext{
${ }^{1}$ STEM stands for $\underline{\text { Science, }} \underline{T}$ echnology, Engineering and $\underline{\text { Mathematics. }}$

${ }^{2}$ Bertrand (2011) discussed how these factors complement the traditionally analysed ones in the understanding of actual gender wage gaps.
} 
Table 1: Expected wage gap—conditional estimates

\begin{tabular}{|c|c|c|c|c|}
\hline Article & Country & \multicolumn{2}{|c|}{ Expected wage gap } & Obs. \\
\hline Menon et al. (2012) & Cyprus & \multicolumn{2}{|l|}{$-13 \%$} & \\
\hline Bonnard and Giret (2016) & France & \multicolumn{2}{|l|}{$-16 \%$} & One year after graduation \\
\hline Frick and Maihaus (2016) & Germany & \multicolumn{2}{|l|}{$-13 \%$} & \\
\hline Kiessling et al. (2019) & Germany & $\begin{array}{l}-14 \% \\
-27 \%\end{array}$ & & $\begin{array}{l}\text { Initial wage } \\
\text { At age } 55\end{array}$ \\
\hline $\begin{array}{l}\text { Alonso-Borrego and } \\
\text { Romero-Medina (2015) }\end{array}$ & Spain & \multicolumn{2}{|c|}{$\begin{array}{l}{[-11.7 \%,-20.7 \%]} \\
-31 \%\end{array}$} & $\begin{array}{l}\text { First year university } \\
\text { Junior uni (Education) }\end{array}$ \\
\hline Telezhkina et al. (2019) & Russia & \multicolumn{2}{|l|}{$-14 \%$} & \\
\hline \multirow[t]{2}{*}{ Brunello et al. (2004) } & \multirow[t]{2}{*}{$\begin{array}{l}10 \text { European } \\
\text { countries }^{3}\end{array}$} & Entry & +10 years & \\
\hline & & $\begin{array}{l}-9.8 \% \\
-8.9 \%\end{array}$ & $\begin{array}{l}-23.4 \% \\
-17.8 \%\end{array}$ & $\begin{array}{l}\text { College graduates } \\
\text { High school graduates }^{4}\end{array}$ \\
\hline Filippin and Ichino (2005) & Italy & $\begin{array}{l}+1 \text { year } \\
\text { (explicit) } \\
-8.1 \% \\
-7.6 \% \\
\text { (implicit) } \\
-9.7 \%\end{array}$ & $\begin{array}{l}+10 \text { years } \\
\text { (explicit) } \\
-11.1 \% \\
-7.2 \% \\
\text { (implicit) } \\
-16.1 \%\end{array}$ & $\begin{array}{l}\text { Students from Bocconi } \\
\text { Female students } \\
\text { Male students } \\
\text { If expecting a gap }\end{array}$ \\
\hline Carvajal et al. (2000) & $\begin{array}{l}\text { United } \\
\text { States }\end{array}$ & \multicolumn{2}{|l|}{$-5.9 \%$} & Seniors studying Business \\
\hline
\end{tabular}

Source: authors' review.

Overall, the literature reviewed strongly suggests a gender gap in the wages expected by university students. As presented in Table 1 and Table 2, the average expected wage gap, whether by conditional estimates or sample statistics, was most often not small, ranging from close to 10 per cent to over 20 per cent (reaching 50 per cent in some cases). While it is not be the focus of this study, it is noticeable that the expectation is that throughout their careers the gap will increase, instead of reducing. Also worth special mention are the studies that reveal differentiated wage gap expectations depending on the area of study of respondents' university degrees.

\footnotetext{
${ }^{3}$ Representative and comprehensive in Italy, Germany, Austria, Switzerland, and Portugal

${ }^{4}$ Counterfactual: university graduates were asked what they thought their wage would be if they started working after high school.
} 
Table 2: Expected wage gap—unconditional estimates

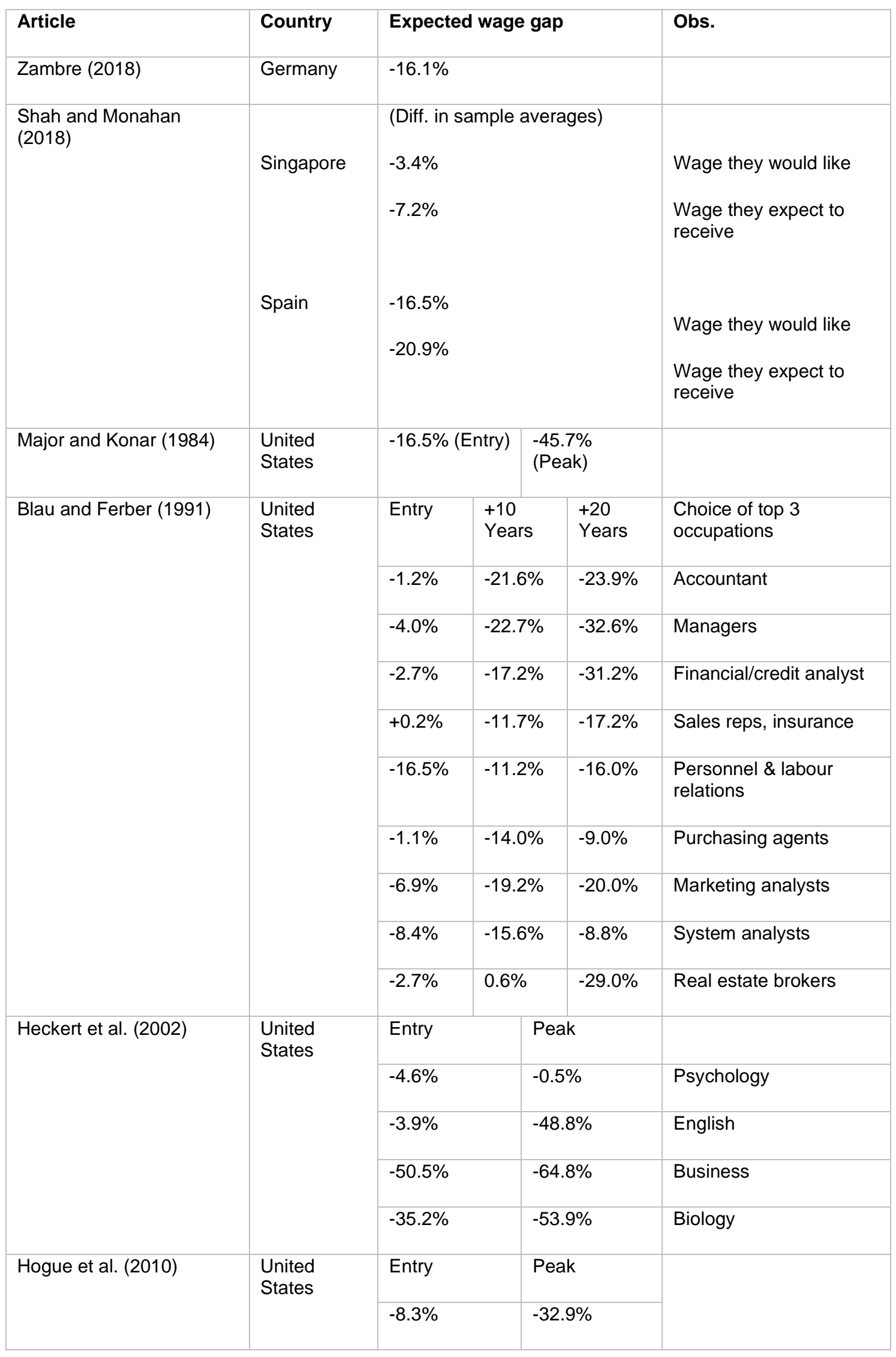




\begin{tabular}{|c|c|c|c|}
\hline Article & Country & Expected wage gap & Obs. \\
\hline \multirow[t]{9}{*}{ Zafar (2013) } & \multirow[t]{9}{*}{$\begin{array}{l}\text { United } \\
\text { States }\end{array}$} & & At age 30 \\
\hline & & $-3.6 \%$ & Natural sciences \\
\hline & & $-37.9 \%$ & $\begin{array}{l}\text { Math and Computer } \\
\text { sciences }\end{array}$ \\
\hline & & $-8.3 \%$ & Social sciences \\
\hline & & $-21.5 \%$ & $\begin{array}{l}\text { Economics \& Math for } \\
\text { Social sciences }\end{array}$ \\
\hline & & $-2.4 \%$ & Ethics and values \\
\hline & & $-36.2 \%$ & Area studies \\
\hline & & $-5.6 \%$ & Literature and Fine Arts \\
\hline & & $-24.7 \%$ & Engineering \\
\hline $\begin{array}{l}\text { Black and Schofield } \\
(2018)^{5}\end{array}$ & $\begin{array}{l}\text { United } \\
\text { States }\end{array}$ & Not significant & Entry pay \\
\hline
\end{tabular}

Source: authors' review.

Finally, it should be noted that, as well as there being evidence that, as students expected, there is a gender gap in the entry wages of university graduates (Bonnard and Giret 2016; Brunello et al. 2004; Francesconi and Parey 2018), there is evidence of consistency between expected and observed wage gaps (Carvajal et al. 2000; Filippin and Ichino 2005; Frick and Maihaus 2016; Kiessling et al. 2019). ${ }^{6}$

While the body of literature is increasing, as can be seen from the tables above, it mostly refers to high-income countries. Only one study was found on the drivers of educational aspirations and expectations of scheduled caste students, in Uttar Pradesh, India (Roy and Kumar 2018), using a qualitative approach. This study is, therefore, the first comparable analysis of the gender gap in expected wages of university students that has been applied to a low-income country. It allows a first glimpse of whether university students in a much different economy expect a wage gap along gender lines; offers an estimate of that gap; and seeks to explain some of its drivers, namely by looking at segregation and segmentation in course choice and preferred area of study and decomposing wage expectations along the two gender identities.

In the following section we focus on the context of our study and describe the variables used in our analysis.

\footnotetext{
${ }^{5}$ Unconditional expectations: results of $\mathrm{t}$-tests

${ }^{6}$ Diaz-Serrano and Nilsson (2017), however, found evidence to the contrary and stated that individual perceptions about future earnings were mostly noise.
} 


\section{Wage expectations of university students in Mozambique}

Mozambique is a low-income country in sub-Saharan Africa characterized by a large subsistence agricultural sector, and with a substantial gender gap in employment out of the subsistence sector, which has widened over time due to the lower level of female human capital and the lower conditional employment probabilities of married women, as compared with men (Gradín and Tarp 2019). Only a small proportion of the population are able to obtain a college degree in Mozambique, but this share is expected to keep growing over time and has already been identified as playing an important role in explaining the recent rise in inequality in the country because it increasingly accrues a disproportional share of total consumption (Gradín 2020a; Gradín and Tarp 2019).

In 2017, the Mozambican Eduardo Mondlane University together with UNU-WIDER and the University of Copenhagen initiated a longitudinal Survey of School to Work Transition of University Students in Mozambique (S2WMozUni 2018a, 2019), in collaboration with the Ministry of Labour and the Ministry of Higher Education of the Government of Mozambique. The survey had two phases: a baseline survey, conducted in 2017, and a phone-based tracer survey, conducted over a period of 18 months from March 2018. The baseline survey was conducted in the Maputo and Beira campuses of six of the most important universities in Mozambique, which together represented 75 per cent of the country's academic population. A total of 2,175 final-year students from 106 courses in 27 different faculties were interviewed. The sample is presented in Table 3.

Table 3: Survey sample, by gender and study area

\begin{tabular}{lrrr}
\hline Study area & Men & Women & All \\
Education & 228 & 226 & 454 \\
Letters and humanities & 57 & 49 & 106 \\
Social sciences & 347 & 463 & 810 \\
Natural sciences & 244 & 81 & 325 \\
Engineering & 158 & 37 & 195 \\
Agronomy & 54 & 37 & 91 \\
Health & 47 & 105 & 152 \\
Services & 15 & 26 & 41 \\
& 1,150 & 1,024 & 2,174 \\
\hline
\end{tabular}

Source: S2WMozUni (2018b).

The baseline survey's findings give clear indications that female final-year students expect a lower wage, on average, than their male counterparts from similar areas of study, as per Figure 1 and Table 4. 
Figure 1: Mean average expected wage, by gender and study area

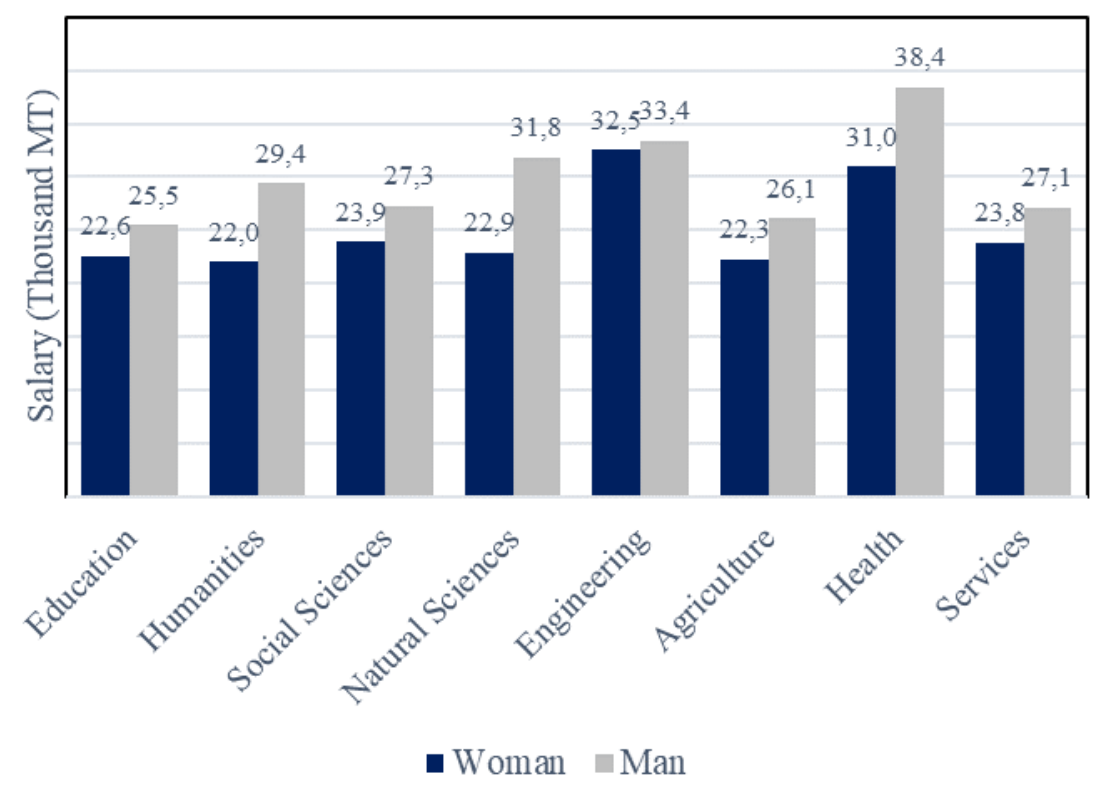

Source: S2WMozUni (2018b).

Table 4: t-tests of equal mean expected wages, men and women final-year university students, by preferred sector of activity

\begin{tabular}{|c|c|c|c|c|c|c|c|c|}
\hline \multirow[b]{2}{*}{ Preferred sector } & \multicolumn{6}{|c|}{ Average wage (MT) } & \multicolumn{2}{|c|}{$\mathbf{N}$} \\
\hline & M & $\mathbf{W}$ & Dif & Std. Error & t stat & $\begin{array}{c}p \\
\text { value }\end{array}$ & M & $\mathbf{W}$ \\
\hline $\begin{array}{l}\text { Agriculture and } \\
\text { fishery }\end{array}$ & $24,510.87$ & $23,382.98$ & $1,127.89$ & $2,562.65$ & .45 & .661 & 46 & 47 \\
\hline $\begin{array}{l}\text { Extractive and } \\
\text { manufacturing } \\
\text { industries }\end{array}$ & $31,609.38$ & $30,179.49$ & $1,429.89$ & $2,971.35$ & .5 & .631 & 128 & 39 \\
\hline $\begin{array}{l}\text { Transport, energy, } \\
\text { communications and } \\
\text { technology }\end{array}$ & $29,206.05$ & $25,083.71$ & $4,122.34$ & $1,314.43$ & 3.15 & .002 & 347 & 182 \\
\hline $\begin{array}{l}\text { Trade, financial } \\
\text { services and other } \\
\text { services }\end{array}$ & $28,864.15$ & $24,584.81$ & $4,279.34$ & 827.82 & 5.15 & 0 & 503 & 666 \\
\hline Mozambique & $29,212.94$ & $24,878.92$ & $4,334.02$ & 642.49 & 6.75 & 0 & 1,041 & 948 \\
\hline
\end{tabular}

Note: t-tests calculated using (S2WMozUni 2018a).

Source: S2WMozUni (2018a). 
A further suggestion of a gender gap in expected wages is found in Figure 2, which depicts the non-parametric probability densities of wages expected by male and female university graduates. The figure shows that the expected wage distribution of males is shifted right from the females', suggesting a gap throughout all the expected wage values. ${ }^{7}$

Figure 2: Expected wage by gender: non-parametric density (adaptive kernel)

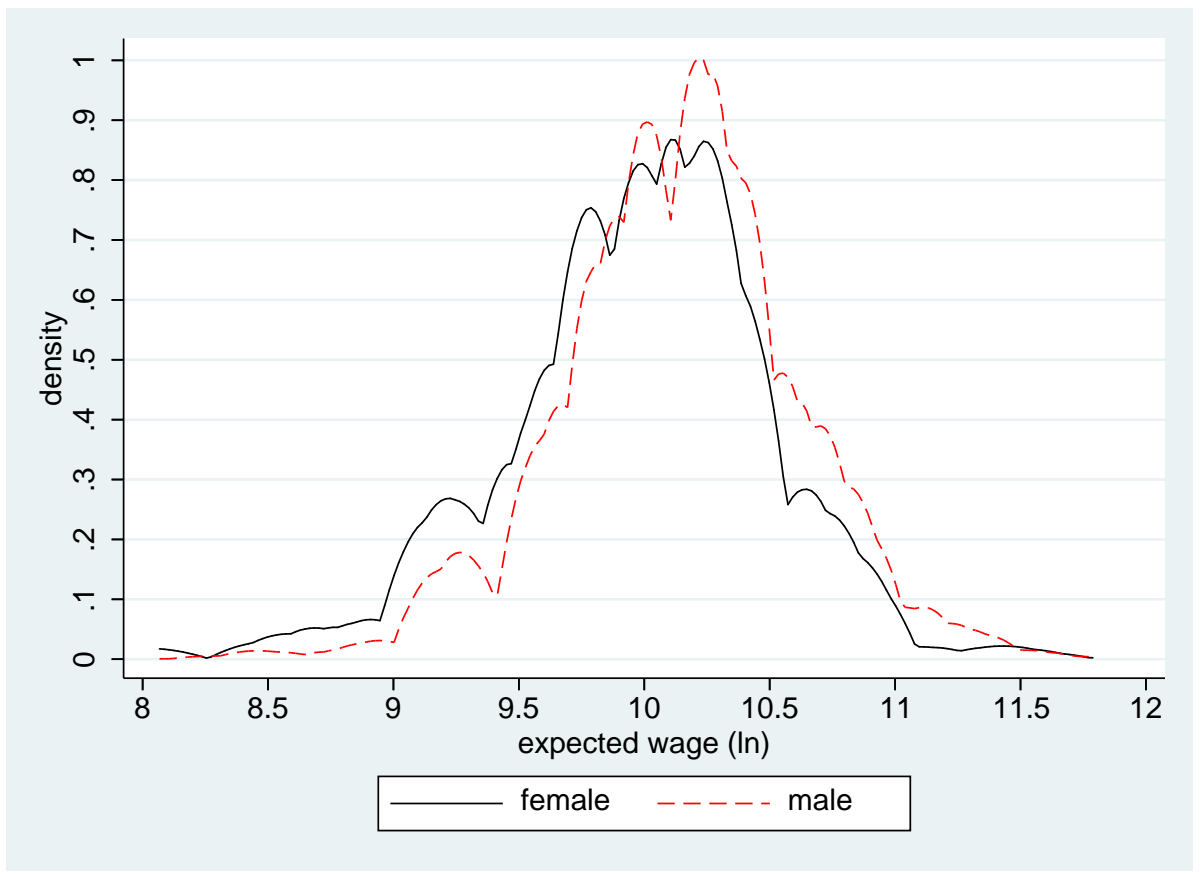

Source: authors' calculations using S2WMozUni (2018a).

As indicated by the descriptive findings reviewed, there is a strong suggestion of a gender gap in the expected wages of Mozambican university graduates. As already discussed, this gender gap is in accordance with the empirical literature, based on middle- and high-income countries. Building on the same literature, we seek to assess what may be behind it.

Following Black and Schofield (2018), we study the factors that influence wage expectations along three groups of covariates: family influences, demographic influences, and academic influences. Within these we find our variables: family influences such as family income, level of education in the household, and previous work experience; demographic influences such as gender, origin of students, or site of university; and academic influences such as years of study, choice/preference of degree, abilities, effort, and academic performance or type of university. Following Bonnard and Giret (2016) and Reuben et al. (2017), we also add factors such as perceptions of personal characteristics and expectations about academic performance.

Table 5 briefly describes the S2WMozUni (2018) data, focusing on these covariates. It is noticeable that the age profiles of men and women final-year students are quite similar, even though men are more prevalent in the second age bracket-25- to 34-year-olds. A significant minority of both male and, more so, female final-year students are already married. The average family education profiles

\footnotetext{
${ }^{7}$ Densities, while they are smooth estimates, show a tendency to report round numbers such as 15,000 and 20,000 MT, a statistical phenomenon known as heaping. The lack of precision also results from the fact that these are expected values, not real ones.
} 
of female and male university final-year students are also similar, although there is a higher prevalence of women from households with professional or higher education.

When looking at the province where they completed primary school, the origins of female and male university finalists are, again, relatively similar, although a higher percentage of male students came from outside the two provinces where the campuses visited are located (Maputo City and Sofala) and from villages (instead of towns and cities), which probably explains the slightly higher percentage of male scholarship recipients and of those that had to relocate to attend university. If, as expected, these scholarships were based on merit, it may also be possible that students from outer provinces and scholarship recipients are more driven and potentially more ambitious than their colleagues, irrespective of gender. A higher percentage of male university students completed secondary education in a public high school. Notably, however, the distribution of women and men between universities appears similar once again. Equally, we find no large gender difference in the high percentage of university students who are satisfied with their choice of academic course.

There is some evidence of differences in the profiles of perceived skills with, in general, higher proportions of men reporting higher proficiency in English and higher than average academic performance than their peers. While, on average, male university finalists outperformed their female peers in analytic, verbal, and numeric tests, the differences are not high. On average, both male and female final-year students completed their degrees in the normal expected time (4 years). On average, also, both female and male final-year students show a locus of control index of 7.7, meaning that, while balanced, both gender groups tend to assume that more control over their lives is external to them rather than in their own hands. ${ }^{8}$

Some indicators allow us to obtain information about previous experience of the labour market. Notably, while there is no great difference in the percentages of men and women who have already had an internship, the prevalence of those who have already worked is significantly higher among male final-year students compared to their female peers.

Remarkably, there is evidence of differences between female and male final-year students in some of the covariates that the literature suggested may have an influence on how they construct wage expectations, while less so on others. In the next section, we present the methodology applied to assess whether these differences sufficiently explain the unequal wage expectations of final-year students in Mozambique by gender.

\footnotetext{
${ }^{8}$ Locus of control was derived from a set of statements regarding control over life events which respondents were asked to agree or disagree with. An index between 1 and 12, with a mean of 7 , is generated, where 1 means the locus of control is fully internal (i.e. the respondents' answers all indicated that they believe they have full control over their lives) and 12 means the locus is fully external (i.e. the respondents believe all events in their lives are beyond their control).
} 
Table 5: Sample characteristics by gender

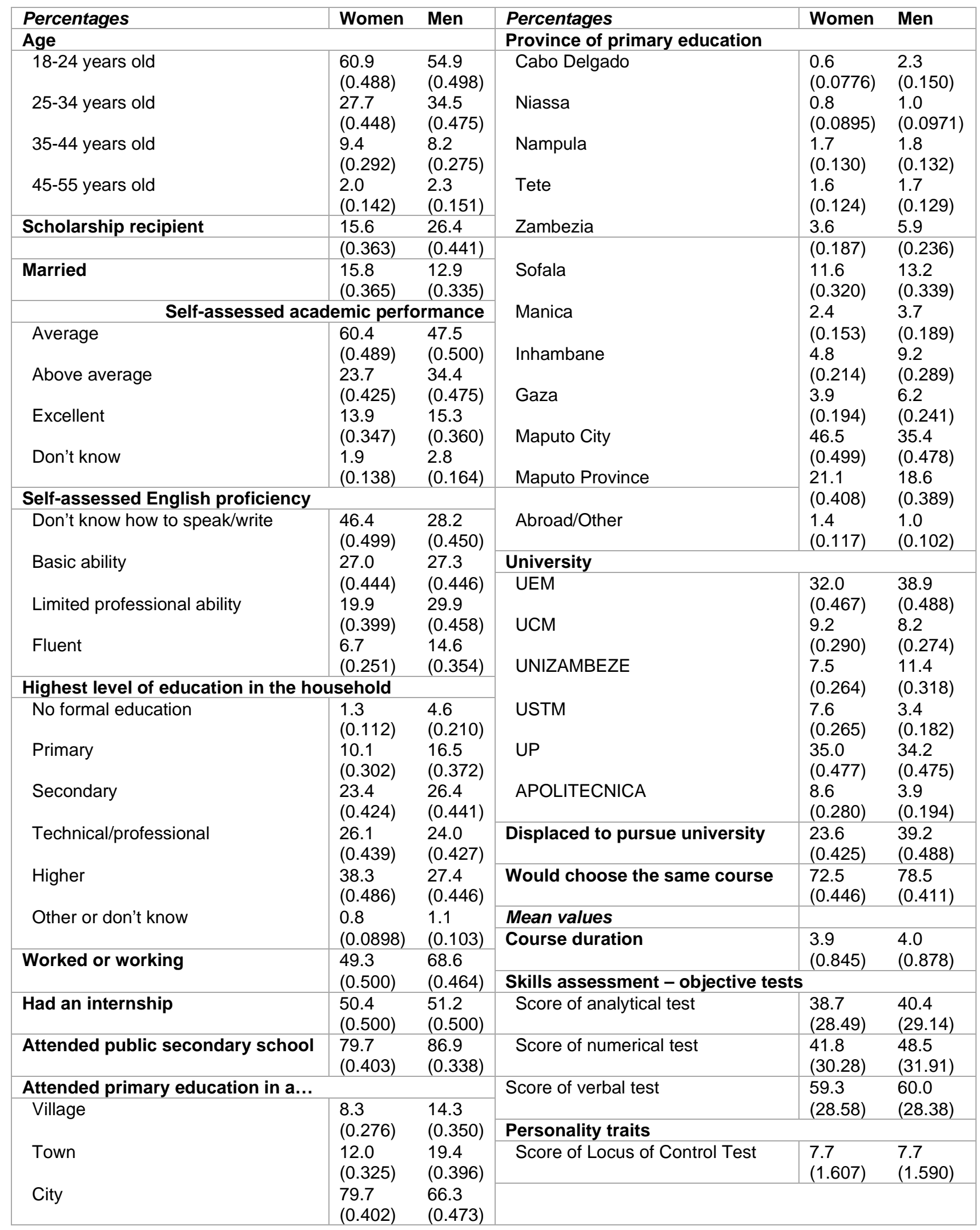

Note: standard deviations in parentheses.

Source: authors' calculations using S2WMozUni (2018a). 


\section{$4 \quad$ Methodology}

\subsection{Segregation and stratification}

Due to the relevance of the area of study and preferred sector of activity for determining wages, we first examine the extent to which men and women study in the same areas or expect to work in the same sector (gender segregation). After that, we examine the extent to which these differences imply that one gender tends to be in the categories (areas of study or sectors) with the lowest average expected wages (gender stratification or segmentation). Here, we follow the methodology proposed by Gradín (2018).

We measure segregation using two indices: Dissimilarity and Gini. The Dissimilarity index measures the average gender difference in the composition of different categories (areas, sectors, or the combination of both):

$$
D=\frac{1}{2} \sum_{j=1}^{N}\left|\frac{n_{f}^{j}}{n_{f}}-\frac{n_{m}^{j}}{n_{m}}\right|
$$

where $n_{g}^{j} / n_{g}$ is the ratio of students of each sex (with $g=f$ for woman; $g=m$ for man) in category $j$ and the total students of that sex.

When categories are ranked by increasing values of the 'men to women ratio' $n_{m}^{j} / n_{f}^{j}$, the Gini index $(\mathrm{G})$ is a weighted average of the difference between the cumulative proportion of women and men for each category:

$$
\begin{aligned}
& G=2 \sum_{j=1}^{N}\left(\hat{F}_{f}^{j}-\hat{F}_{m}^{j}\right) \frac{n_{f}^{j}}{n_{f}} \\
& \text { with } \hat{F}_{g}^{j}=\sum_{i=1}^{j-1} \frac{n_{g}^{j-1}}{n_{g}}+\frac{1}{2} \frac{n_{g}^{j}}{n_{g}} .
\end{aligned}
$$

Both indices take the value 0 when there is no segregation (the distributions of men and women are identical), and 1 when segregation is maximum (we find only men or women in each category, but not both). Index D can also be expressed as the absolute value of the difference between the proportion of men and women in the set of categories with the highest proportion of one gender. Therefore, it has the intuitive interpretation of indicating the percentage of students of one gender (male or female) who should switch categories (from those dominated by their gender to those dominated by the other gender), to completely eliminate segregation. The Gini index is a more complete index because it also takes account of the segregation within these two major sets of categories, therefore being always higher than D. Graphically, the Gini index can be expressed as double the area that lies between the segregation curve (which represents the ratio of women accumulated for each accumulated proportion of men) and the diagonal (representing the curve for no segregation, when both proportions are equal).

Not all types of segregation have the same implications. Men and women may be in different categories, but with no systematic difference in expected wages between the categories filled by both genders. This is a type of horizontal (or pay-neutral) segregation. Segregation is vertical, however, when the categories are stratified by gender, with one tending to be over-represented in low-paying categories. We measure the segregation of women into low-paying categories using the 
Gini concentration index $\mathrm{C}$ (the Gini calculated on the distribution of men and women, $H_{g}$, with the categories ordered by their expected average wage instead of by the men to women ratio):

$$
C=2 \sum_{j=1}^{N}\left(\widehat{H}_{f}^{j}-\widehat{H}_{m}^{j}\right) \frac{n_{f}^{j}}{n_{f}}
$$

The concentration index takes values between $-G$ and $G$. It takes the highest value when all women's segregation is into low-paying categories, that is, there is a perfect correlation between the order of categories by average wage and the order of categories by the men to women ratio. The concentration index will take its lowest value when segregation of women is into high-paying categories instead. That is, the correlation mentioned above is negative. More generally, a positive value of the index indicates a tendency for women to be over-represented in low-paying categories, and a negative value indicates that they are over-represented in high-paying categories (and therefore men are segregated into low-paying categories). When gender segregation is pay neutral, the index is 0 .

To analyse the extent to which gender segregation (or stratification) is the result of a compositional effect (that is, men and women have a different distribution of characteristics that might influence the choice of study area or sector of activity), we use a counterfactual in which the female sample is reweighted to reproduce the male distribution of characteristics. ${ }^{9}$ Segregation in this counterfactual distribution is 'conditional segregation' (or unexplained), whereas the difference between observed and counterfactual segregation is the part of segregation attributable to the compositional effect (explained segregation).

\subsection{Wage gap}

To explain the difference in average expected wage between male and female final-year students, we employed the procedure initially proposed by Blinder (1973) and Oaxaca (1973), which consists of estimating a Mincerian regression of the log of expected wages $(Y)$ as a function of a set of characteristics associated with student productivity $(X)$. The equation is estimated separately for men and women using ordinary least squares (OLS):

$$
Y_{g}=X_{g} \beta_{g}+\varepsilon_{g} ; E\left(Y_{g}\right)=X_{g} \beta_{g}
$$

Oaxaca and Ransom (1999) proposed deriving the wage structure that would prevail in the absence of discrimination by gender, from an estimation for the pooled sample (men and women). Here, we follow the specification by Jann (2008), which proposes adding a gender dummy ( $m=1$ if male; 0 if female) among the dependent variables in the regression to produce a clearer decomposition:

$$
Y=X \beta+\alpha m+\varepsilon
$$

The average expected sex wage gap (in logs) can be divided into two terms:

$$
E\left(Y_{m}\right)-E\left(Y_{f}\right)=\left[X_{m}\left(\beta_{m}-\beta\right)-X_{f}\left(\beta_{f}-\beta\right)\right]+\left(X_{m}-X_{f}\right) \beta
$$

\footnotetext{
${ }^{9}$ Reweighting is done using propensity score, after estimating a logit regression of the probability of being a man over a set of individual characteristics (including interactions).
} 
The second term $\left(X_{m}-X_{f}\right) \beta$ is the part of the gender pay gap that is explained by gender differences in the mean values of characteristics (characteristics or compositional effect). The first term is the gender pay gap that remains unexplained after controlling for characteristics, i.e. the coefficients or wage structure effect (sum of male advantage and female disadvantage with respect to the reference structure). By construction, this unexplained effect is equal to the coefficient of the sex dummy, $\alpha=E\left(Y_{m}-Y_{f} \mid X\right)$, in the pooled estimation. If the model specification is correct, this term can be interpreted as gender discrimination, which in our case would be anticipated by students before entering the labour market.

Similarly, we use the extension of this Blinder-Oaxaca procedure proposed by Firpo et al. (2018, 2009) to explain the gender difference at different points in the expected wage distribution, such as the median, or the extremes. For this, we replace $Y$ in the regression with the value of the Recentered Influence Function (RIF) for any quantile $Q_{\tau}$ of interest (with $\tau=$ $5,10, \ldots, 50, \ldots, 95)$, where $\gamma$ represents the corresponding coefficients: ${ }^{10}$

$$
E\left(R I F\left(Y_{g} ; Q_{\tau}\right)\right)=X_{g} \gamma_{g}
$$

Thus, we decompose the observed gender wage gap in the $\boldsymbol{\tau}^{\text {th }}$ quantile into two terms, unexplained (wage structure effect) and explained (compositional effect):

$$
Q_{\tau}\left(Y_{m}\right)-Q_{\tau}\left(Y_{f}\right)=\left[X_{m}\left(\gamma_{m}-\gamma\right)-X_{f}\left(\gamma_{f}-\gamma\right)\right]+\left(X_{m}-X_{f}\right) \gamma
$$

In all cases, difference in mean and in different quantiles, the aggregate decomposition is presented along a detailed decomposition with the contribution of each variable (or set of variables) to explain the total observed gap. It should be noted, however, that the detailed decomposition of the coefficients effect has an identification problem since the contribution of the different characteristics may vary depending on which category was omitted to avoid the multicollinearity problem or on the scale used to construct continuous variables (see discussion in Fortin et al. 2011).

In the next section we discuss the results obtained from applying this methodology.

\section{$5 \quad$ Results}

We start by discussing the results of gender segregation and stratification by area of study and by preferred sector of activity, and then discuss the gender differences in expected wages in the first month of work.

\subsection{Gender segregation by area of study and sector of activity}

The results shown in Table 7 (first column highlights the existence of gender segregation of students by area of study and by preferred sector of activity). According to the D index, to eliminate gender differences by area of study, approximately 12 per cent of female students (or male students) would have to switch their respective area of study (from areas where their gender

\footnotetext{
${ }^{10} R I F\left(Y ; Q_{\tau}\right)$ indicates the expected change in quantile $Q_{\tau}$ when the proportion of population in $Y$ is marginally increased (i.e. the impact of a small contamination at $Y$ ). Fortin et al. (2011) provide a detailed discussion of the properties of this procedure and its alternatives.
} 
is over-represented to those where it is under-represented). A relatively higher percentage (14 per cent) of women would have to change their preferred sector of activity to correct segregation. The combination of area of study and sector of activity also varies by gender, so that if we consider both at the same time, around 24 per cent of men (or women) would have to change their respective combined categories to eliminate segregation. The Gini index is relatively higher than the $\mathrm{D}$ index, as it also includes the segregation that exists among categories dominated by one gender. In general, the Gini index shows a stronger segregation by preferred sector of activity than by area of study (Gini of 0.197 compared to 0.358 ), a segregation that intensifies when looking at those dimensions combined (Gini of 0.358).

Table 6: Gender segregation and segmentation across areas of study and preferred sectors of activity

\section{Observed Conditional}

\section{Study area $(\mathrm{N}=13)$}

$\begin{array}{lll}\text { Segregation (D) } & 0.117 & 0.142 \\ \text { Segregation (Gini) } & 0.180 & 0.178 \\ \text { Concentration (Gini) } & 0.072 & -0.012 \\ \text { Ratio (\%C/S) } & 40.3 & -6.7 \\ \text { Sector of activity (N=13) } & \\ \text { Segregation (D) } & 0.138 & 0.136 \\ \text { Segregation (Gini) } & 0.197 & 0.194 \\ \text { Concentration (Gini) } & -0.035 & -0.060 \\ \text { Ratio (\%C/S) } & -17.8 & -31.1 \\ \text { Study area and sector of activity (N=135) } & & \\ \text { Segregation (D) } & 0.236 & 0.252 \\ \text { Segregation (Gini) } & 0.358 & 0.366 \\ \text { Concentration (Gini) } & 0.056 & 0.006 \\ \text { Ratio (\%C/S) } & 0.156 & 1.6\end{array}$

Note: standard error (200 bootstraps) in parentheses. * Segregation and concentration are measured in the counterfactual distribution, reweighted by the variables in Table 5, except for university, including interactions.

Source: authors' calculations using S2WMozUni (2018a).

The fact that female and male students are found in different areas of study does not necessarily mean that one group, say female students, should expect lower wages. But, as shown in Table 7, this is what happens to some extent. Women are especially under-represented in areas of study with high expected wages, such as engineering and information sciences, but also in areas of study with low expected wages, such as agriculture or education. Concurrently, women are overrepresented in low expected wage areas of study, such as social sciences, accounting, psychology and, especially, education management. The Gini concentration index of 0.072 in Table 6 confirms that women tend to be segregated, on average, into areas of study with lower expected wages. About 40 per cent of the observed segregation is of this type (vertical), while the rest is horizontal segregation with no direct impact on the expected wage. 
Table 7: Distribution of areas of study by gender

\begin{tabular}{|c|c|c|c|c|c|c|c|}
\hline \multirow[b]{2}{*}{ Area of study } & \multicolumn{5}{|c|}{ Observed } & \multicolumn{2}{|c|}{ Conditional } \\
\hline & $\begin{array}{c}\% \\
\text { Total }\end{array}$ & $\begin{array}{c}\text { Expected } \\
\text { wage (MT) }\end{array}$ & $\begin{array}{c}\% \\
\text { Women }\end{array}$ & $\begin{array}{c}\% \\
\text { Men }\end{array}$ & Dif. & $\begin{array}{c}\% \\
\text { Women }\end{array}$ & Dif. \\
\hline Health sciences & 5.1 & 35,622 & 4.9 & 5.3 & 0.4 & 8.4 & -3.0 \\
\hline Engineering & 7.9 & 33,118 & 5.6 & 9.7 & 4.1 & 7.1 & 2.6 \\
\hline Information science & 1.9 & 31,524 & 1.1 & 2.6 & 1.5 & 1.5 & 1.1 \\
\hline Natural science & 2.1 & 30,698 & 2.2 & 2.0 & -0.1 & 3.2 & -1.1 \\
\hline Accounting & 5.6 & 27,196 & 6.4 & 5.0 & -1.4 & 5.5 & -0.5 \\
\hline Law & 5.8 & 26,813 & 6.1 & 5.6 & -0.5 & 4.3 & 1.3 \\
\hline Humanities & 1.6 & 26,286 & 1.5 & 1.6 & 0.1 & 1.5 & 0.1 \\
\hline Social sciences & 9.0 & 25,816 & 9.6 & 8.6 & -1.0 & 11.3 & -2.7 \\
\hline Psychology & 5.7 & 25,670 & 7.0 & 4.6 & -2.4 & 7.2 & -2.6 \\
\hline Agriculture & 5.5 & 25,617 & 3.7 & 7.0 & 3.3 & 4.7 & 2.3 \\
\hline Economics and management & 20.3 & 24,846 & 20.5 & 20.2 & -0.4 & 15.6 & 4.6 \\
\hline Education & 22.1 & 24,464 & 20.8 & 23.1 & 2.3 & 19.6 & 3.5 \\
\hline Education management & 7.3 & 23,340 & 10.6 & 4.7 & -5.9 & 10.3 & -5.5 \\
\hline Total & 100 & 26,506 & 100 & 100 & & 100 & \\
\hline
\end{tabular}

Source: authors' calculations using S2WMozUni (2018a).

On the other hand, regarding the preferred sector of activity (Table 8), women tend to be underrepresented at both extremes of the distribution in terms of pay, high-wage sectors (construction and extractive industries), and low-wage sectors (communications and technology, education, and commerce), while being strongly over-represented in sectors with intermediate expected wages such as health, financial activities, or public administration. Therefore, even though gender segregation is higher by sector of activity than by area of study, its nature is different, since it is men who are over-represented in sectors with low expected wages (indicated by a negative Gini concentration index of -0.035 in Table 7). Men and women may expect to perform different tasks even within each sector of activity if they come from different fields. When both study area and sector of activity are considered together, we observe that women tend to be over-represented in lower expected wage categories, with their preferred sector mitigating the effect of their area of study (Gini concentration index of 0.056).

As suggested by the literature, some of the gender-based segregation and segmentation can be explained by the different characteristics of female and male students, already discussed for our case. Only a small proportion of students are able to complete tertiary studies in a developing country like Mozambique and this selection into university can be different by gender. Indeed, selection is somewhat more pronounced among women, given that they represent 45 per cent of students (weighted sample). In addition, there are gender differences by skill and other characteristics. 
Table 8: Distribution of desired sector of activity by gender

\begin{tabular}{|c|c|c|c|c|c|c|c|}
\hline \multirow[b]{2}{*}{ Sector } & \multicolumn{5}{|c|}{ Observed } & \multicolumn{2}{|c|}{ Conditional } \\
\hline & $\begin{array}{c}\% \\
\text { Total }\end{array}$ & $\begin{array}{c}\text { Expected } \\
\text { wage (MT) }\end{array}$ & $\begin{array}{c}\% \\
\text { Women }\end{array}$ & $\begin{array}{c}\% \\
\text { Men }\end{array}$ & Dif. & $\begin{array}{c}\% \\
\text { Women }\end{array}$ & Dif. \\
\hline Construction & 4.4 & 31,906 & 3.6 & 5.0 & 1.5 & 3.5 & 1.5 \\
\hline Extractive industry & 3.6 & 30,288 & 1.9 & 5.0 & 3.1 & 2.9 & 2.1 \\
\hline Don't know/No work & 1.6 & 30,089 & 1.5 & 1.7 & 0.2 & 0.8 & 0.8 \\
\hline Transport & 1.0 & 29,862 & 0.8 & 1.2 & 0.3 & 0.7 & 0.4 \\
\hline Health & 9.3 & 29,780 & 12.2 & 6.9 & -5.4 & 18.4 & -11.5 \\
\hline Financial activities & 18.0 & 27,996 & 19.5 & 16.8 & -2.7 & 15.6 & 1.2 \\
\hline Manufacturing industry & 3.1 & 27,957 & 1.9 & 4.0 & 2.1 & 2.8 & 1.2 \\
\hline Restaurant and accommodation & 1.8 & 27,573 & 2.5 & 1.3 & -1.2 & 1.4 & -0.1 \\
\hline Public administration & 10.9 & 25,714 & 13.4 & 8.9 & -4.4 & 10.4 & -1.4 \\
\hline Communications and technology & 8.8 & 25,479 & 7.3 & 10.1 & 2.8 & 8.8 & 1.3 \\
\hline Agriculture and fishery & 3.6 & 24,681 & 3.4 & 3.8 & 0.3 & 3.6 & 0.1 \\
\hline Education & 29.0 & 24,315 & 28.3 & 29.6 & 1.3 & 26.7 & 2.9 \\
\hline Commerce & 5.0 & 22,152 & 3.9 & 5.9 & 2.0 & 4.5 & 1.4 \\
\hline Total & 100 & 26,506 & 100 & 100 & & 100 & \\
\hline
\end{tabular}

Source: authors' calculations using S2WMozUni (2018a).

The results from Table 7 (second column), when we compare men and women with the same characteristics (those included on Table 6 except for university and including interactions), suggest that gender segregation by area of study and by preferred sector of activity is not explained by a compositional effect. After conditioning on initial student characteristics, the estimated segregation barely changes: the Gini for sector of activity changes from 0.197 to 0.194 , while the Gini for area of study changes from 0.180 to 0.178 . The estimated combined segregation (by area and sector) is actually higher (increases from 0.358 to 0.366 ), although with a more balanced gender distribution in terms of expected wages (the concentration index is close to 0 or is even negative). The over-representation of women in higher expected wage sectors increases (concentration index of 0.060), while the under-representation of women in areas of study or combined preferred sector of activity and area of study vanishes. That is, even though initial characteristics do not explain why men and women choose to study in different areas and expect to work in different sectors, they largely explain why women are over-represented in positions (study area and sector of activity) with lower expected wages. ${ }^{11}$

\subsection{Estimating the gender difference in expected wage}

We have already shown that the data strongly suggests that there are significant differences in expected wages by male and female final-year university students throughout the distribution. Table 9 reports the Mincerian regressions for the pool of students (first two columns) and for each gender (remaining columns). While some determinants are common for women and men, others are gender specific. Ceteris paribus, wages are expected to be higher on average among men and women when the preferred sector of activity is financial activities or restaurants and accommodation. They also tend to be higher for students at Universidade Eduardo Mondlane (UEM)

\footnotetext{
11 These results are in line with others for occupational segregation in South Africa or the United States. (Gradín 2018, 2020b).
} 
or at Universidade Politécnica regardless of their gender. Wages are expected to be higher on average for men aged 35 to 44 years who study engineering or health studies, receive a scholarship, or selfreport excellent performance. Expected wages, on the other hand, tend to be higher on average for women who relocate to study, follow longer studies, or who prefer to work in the construction sector, and tend to be lower for women in the field of humanities. It is noteworthy that, ceteris paribus, there are no statistically significant effects on expected wages from other relevant wage determinants related to their family and individual background, location, or skills.

The pooled regressions for men and women indicate that, after controlling for all these personal and family characteristics, a large gender gap remains (0.129 in log terms) and is statistically significant, rejecting the hypothesis that the expected wage gap is the result of gender differences in the distribution of these characteristics. Thus, only a fifth (21.5 per cent) of the initial wage gap of 0.164 can be explained by a compositional effect, when the reference wage structure (returns to characteristics) is the pooled sample of men and women.

Table 9: Expected wage regression (In)

\begin{tabular}{|c|c|c|c|c|c|c|}
\hline \multirow[b]{2}{*}{ Numerical abilities } & \multicolumn{2}{|c|}{ Men and Women } & \multicolumn{2}{|c|}{ Women } & \multicolumn{2}{|c|}{ Men } \\
\hline & 0.000 & $(0.000)$ & 0.001 & $(0.001)$ & -0.001 & $(0.001)$ \\
\hline Verbal abilities & -0.000 & $(0.000)$ & 0.001 & $(0.001)$ & -0.001 & $(0.001)$ \\
\hline Analytical abilities & 0.000 & $(0.000)$ & -0.000 & $(0.001)$ & 0.001 & $(0.001)$ \\
\hline Locus score & 0.002 & $(0.008)$ & -0.011 & $(0.012)$ & 0.010 & $(0.010)$ \\
\hline 25-34 years old & 0.032 & $(0.032)$ & -0.010 & $(0.049)$ & 0.057 & $(0.042)$ \\
\hline 35-44 years old & $0.161^{* *}$ & $(0.055)$ & 0.065 & $(0.083)$ & $0.265^{\star \star \star}$ & $(0.069)$ \\
\hline 45-55 years old & 0.158 & $(0.096)$ & 0.221 & $(0.121)$ & 0.155 & $(0.145)$ \\
\hline Receives scholarship & $0.081^{* *}$ & $(0.031)$ & 0.053 & $(0.053)$ & $0.087^{\star}$ & $(0.040)$ \\
\hline Relocated for university & 0.059 & $(0.033)$ & $0.139 *$ & $(0.062)$ & 0.008 & $(0.038)$ \\
\hline Has children & 0.008 & $(0.034)$ & 0.053 & $(0.053)$ & -0.024 & $(0.045)$ \\
\hline Married & 0.050 & $(0.039)$ & 0.088 & $(0.054)$ & 0.022 & $(0.058)$ \\
\hline Ever had a paid job & 0.033 & $(0.026)$ & 0.050 & $(0.038)$ & 0.029 & $(0.035)$ \\
\hline Had a prior internship & 0.052 & $(0.029)$ & 0.060 & $(0.045)$ & 0.031 & $(0.039)$ \\
\hline Performance: > average & 0.035 & $(0.027)$ & 0.051 & $(0.040)$ & 0.027 & $(0.037)$ \\
\hline Performance: excellent & $0.088^{*}$ & $(0.035)$ & 0.079 & $(0.053)$ & $0.112^{*}$ & $(0.048)$ \\
\hline Performance: don't know & 0.087 & $(0.090)$ & 0.069 & $(0.207)$ & 0.130 & $(0.071)$ \\
\hline Course duration & $0.040^{* *}$ & $(0.012)$ & 0.046 ** & $(0.016)$ & 0.035 & $(0.019)$ \\
\hline Secondary education: public & 0.022 & $(0.033)$ & 0.008 & $(0.051)$ & 0.010 & $(0.043)$ \\
\hline Basic English skill & -0.022 & $(0.031)$ & -0.018 & $(0.040)$ & -0.023 & $(0.046)$ \\
\hline Limited professional English skill & -0.002 & $(0.033)$ & -0.063 & $(0.053)$ & 0.038 & $(0.042)$ \\
\hline Fluent/ professional English skill & -0.024 & $(0.046)$ & 0.025 & $(0.086)$ & -0.043 & $(0.057)$ \\
\hline Choose same course? & -0.012 & $(0.021)$ & 0.020 & $(0.030)$ & -0.035 & $(0.028)$ \\
\hline Family of growth: No formal education & -0.073 & $(0.090)$ & -0.079 & $(0.242)$ & -0.061 & $(0.094)$ \\
\hline Family of growth: Primary education & 0.058 & $(0.041)$ & 0.061 & $(0.067)$ & 0.053 & $(0.053)$ \\
\hline Family of growth: Secondary education & -0.012 & $(0.032)$ & 0.030 & $(0.047)$ & -0.035 & $(0.044)$ \\
\hline Family of growth: Professional and technical & 0.007 & $(0.033)$ & -0.036 & $(0.049)$ & 0.039 & $(0.046)$ \\
\hline Family of growth: Other/don't know & -0.122 & $(0.156)$ & -0.192 & $(0.153)$ & -0.049 & $(0.235)$ \\
\hline EP: Cabo Delgado & 0.030 & $(0.092)$ & -0.248 & $(0.240)$ & 0.049 & $(0.095)$ \\
\hline EP: Gaza & 0.010 & $(0.063)$ & 0.023 & $(0.112)$ & 0.035 & $(0.079)$ \\
\hline EP: Inhambane & -0.066 & $(0.061)$ & 0.016 & $(0.099)$ & -0.081 & $(0.075)$ \\
\hline EP: Manica & 0.042 & $(0.084)$ & 0.179 & $(0.153)$ & -0.027 & $(0.095)$ \\
\hline EP: Maputo Province & -0.025 & $(0.034)$ & -0.044 & $(0.052)$ & 0.001 & $(0.045)$ \\
\hline EP: Nampula & -0.137 & $(0.121)$ & -0.029 & (0.128) & -0.234 & (0.178) \\
\hline
\end{tabular}




\begin{tabular}{|c|c|c|c|c|c|c|}
\hline EP: Niassa & -0.005 & $(0.124)$ & 0.331 & $(0.184)$ & -0.169 & $(0.140)$ \\
\hline EP: Abroad/ Other & -0.157 & $(0.144)$ & -0.401 & $(0.221)$ & 0.098 & $(0.176)$ \\
\hline EP: Sofala & -0.073 & $(0.051)$ & -0.071 & $(0.086)$ & -0.073 & $(0.065)$ \\
\hline EP: Tete & -0.119 & $(0.085)$ & -0.147 & $(0.130)$ & -0.098 & $(0.102)$ \\
\hline EP: Zambezia & 0.029 & $(0.072)$ & -0.180 & $(0.110)$ & 0.133 & $(0.090)$ \\
\hline Primary education: Village (?) & -0.047 & $(0.044)$ & -0.066 & $(0.080)$ & -0.037 & $(0.053)$ \\
\hline Primary education: Town & 0.022 & $(0.035)$ & -0.048 & $(0.060)$ & 0.058 & $(0.045)$ \\
\hline UEM & $0.215^{\star \star \star}$ & $(0.034)$ & $0.194^{\star \star \star}$ & $(0.057)$ & $0.222^{\star \star \star}$ & $(0.044)$ \\
\hline UCM & 0.109 & $(0.069)$ & 0.178 & $(0.101)$ & 0.039 & $(0.102)$ \\
\hline UNIZAMBEZE & 0.008 & $(0.060)$ & 0.059 & $(0.120)$ & -0.028 & $(0.070)$ \\
\hline USTM & 0.071 & $(0.066)$ & 0.075 & $(0.085)$ & 0.119 & $(0.104)$ \\
\hline APOLITECNICA & $0.288^{\star \star \star}$ & $(0.057)$ & $0.341^{\star \star \star}$ & $(0.077)$ & $0.209^{*}$ & $(0.096)$ \\
\hline Education management & -0.029 & $(0.055)$ & -0.106 & $(0.073)$ & -0.010 & $(0.089)$ \\
\hline Humanities & -0.093 & $(0.066)$ & $-0.231^{*}$ & $(0.101)$ & -0.028 & $(0.090)$ \\
\hline Social sciences & -0.042 & $(0.056)$ & -0.032 & $(0.090)$ & -0.054 & $(0.072)$ \\
\hline Economics and management & -0.091 & $(0.054)$ & -0.161 & $(0.087)$ & -0.068 & $(0.071)$ \\
\hline Accounting & -0.109 & $(0.072)$ & -0.146 & $(0.113)$ & -0.105 & $(0.104)$ \\
\hline Law & -0.034 & $(0.072)$ & -0.196 & $(0.108)$ & 0.064 & $(0.096)$ \\
\hline Natural science & 0.017 & $(0.072)$ & -0.105 & $(0.128)$ & 0.065 & $(0.087)$ \\
\hline Information science & 0.137 & $(0.073)$ & 0.215 & $(0.164)$ & 0.121 & $(0.088)$ \\
\hline Engineering & $0.146^{*}$ & $(0.071)$ & -0.069 & $(0.156)$ & $0.214^{\star \star}$ & $(0.082)$ \\
\hline Agriculture & -0.094 & $(0.073)$ & -0.151 & $(0.114)$ & -0.072 & $(0.095)$ \\
\hline Health sciences & $0.232^{\star *}$ & $(0.082)$ & 0.092 & $(0.118)$ & $0.279^{*}$ & (0.119) \\
\hline Psychology & -0.015 & $(0.058)$ & -0.001 & $(0.084)$ & -0.058 & $(0.086)$ \\
\hline Agriculture and fishery & 0.002 & $(0.096)$ & 0.063 & $(0.129)$ & -0.049 & (0.131) \\
\hline Extractive industry & 0.142 & $(0.082)$ & 0.368 & $(0.190)$ & 0.076 & $(0.088)$ \\
\hline Manufacturing industry & 0.078 & $(0.074)$ & 0.135 & $(0.151)$ & 0.074 & (0.083) \\
\hline Construction & 0.105 & $(0.071)$ & $0.371^{*}$ & $(0.145)$ & 0.014 & $(0.084)$ \\
\hline Commerce & -0.011 & $(0.062)$ & 0.080 & (0.109) & -0.078 & $(0.078)$ \\
\hline Restaurant and accommodation & $0.204^{*}$ & $(0.085)$ & $0.295^{\star}$ & $(0.123)$ & $0.245^{\star}$ & $(0.106)$ \\
\hline Transport & 0.243 & $(0.126)$ & 0.314 & $(0.211)$ & 0.215 & (0.159) \\
\hline Communications and technology & 0.004 & $(0.052)$ & -0.012 & $(0.087)$ & 0.024 & $(0.066)$ \\
\hline Financial activities & $0.212^{\star \star \star}$ & $(0.049)$ & $0.208^{\star \star}$ & $(0.080)$ & $0.228^{\star \star \star}$ & $(0.064)$ \\
\hline Public administration & 0.082 & $(0.049)$ & 0.120 & $(0.067)$ & 0.052 & $(0.074)$ \\
\hline Health & 0.047 & $(0.064)$ & 0.017 & $(0.095)$ & 0.129 & $(0.079)$ \\
\hline Don't know/No work & 0.136 & $(0.098)$ & 0.226 & $(0.143)$ & 0.162 & $(0.146)$ \\
\hline Men & $0.129^{\star \star \star}$ & $(0.027)$ & & & & \\
\hline Intercept & $9.537^{\star \star \star}$ & $(0.096)$ & $9.518^{\star \star \star}$ & $(0.129)$ & $9.702^{\star \star \star}$ & $(0.138)$ \\
\hline N & 1,989 & & 948 & & 1,041 & \\
\hline $\mathrm{R}^{2}$ & 16.3 & & 15.9 & & 20.4 & \\
\hline
\end{tabular}

Note: ${ }^{*} p<0.05,{ }^{* *} p<0.01,{ }^{* * *} p<0.001$;

Source: authors' calculations using S2WMozUni (2018a).

The decomposition of the average gender gap in expected wages reported in Table 10 allows us to identify which characteristics determine this limited compositional effect. The different distribution by area of study, discussed previously, is the most noticeable effect, explaining by itself around 7.4 per cent of the average observed difference between genders. The lower proportion of women (compared to men) who receive a scholarship (16 per cent of women versus 27 per cent of men), also accounts for 5 per cent of the total difference. The lower share of women who had 
to relocate to attend university ( 23 per cent versus 39 per cent of men) is also slightly significant, accounting for about another 6 per cent of the total difference.

The aggregate compositional effect is only relevant to explain the gender wage gap in quantiles above the median (Figure 4, Table 10 for selected quantiles, and Table A1 for all). This can also be tracked at the detailed effects level. For example, the impact of gender differences by area of study on the expected wage-gender gap can only be found at the median expected wage or above and is highest at top quantiles. That is, the gender segmentation by area of study, previously discussed, is found to affect the gender gap in expected (highest) wages. Similarly, the proportion of people relocating to study at the university is only significant at the median or above. It is also the case for the lower numerical abilities of female students, which, while having no effect on the mean, have significant and positive effects on intermediate quantiles (between 25 and 50), where the expected wage increases with ability. However, this is compensated for by a negative effect on the expected wage gap at higher quantiles (85 and 90), where, paradoxically, higher abilities tend to lower wage expectations. The lower level in the expected wage-gender gap observed for higher quantiles, therefore, is due, exclusively, to a smaller unexplained difference in the (expected) returns to characteristics (wage structure effect).

Table 10: Expected wage gap decomposition (In)

\begin{tabular}{|c|c|c|c|c|c|c|c|c|}
\hline \multirow{3}{*}{ Total difference } & \multicolumn{4}{|c|}{ Composition effect (explained) } & \multicolumn{4}{|c|}{ Wage structure effect (unexplained) } \\
\hline & Average & Q10 & Q50 & Q85 & Average & Q10 & Q50 & Q85 \\
\hline & $\begin{array}{l}0.164^{\star \star *} \\
(0.025)\end{array}$ & $\begin{array}{l}0.278^{\star \star \star} \\
(0.033)\end{array}$ & $\begin{array}{l}0.238 * * \star \\
(0.029)\end{array}$ & $\begin{array}{l}0.176^{\star \star \star} \\
(0.039)\end{array}$ & $\begin{array}{l}0.164^{\star \star *} \\
(0.025)\end{array}$ & $\begin{array}{l}0.278^{* * *} \\
(0.033)\end{array}$ & $\begin{array}{l}0.238^{\star \star \star} \\
(0.029)\end{array}$ & $\begin{array}{l}0.176^{\star * *} \\
(0.039)\end{array}$ \\
\hline Total effect & $\begin{array}{l}0.035^{\star \star} \\
(0.016)\end{array}$ & $\begin{array}{l}0.012 \\
(0.021)\end{array}$ & $\begin{array}{l}0.035^{\star} \\
(0.018)\end{array}$ & $\begin{array}{l}0.036 \\
(0.025)\end{array}$ & $\begin{array}{l}0.129 * * * \\
(0.026)\end{array}$ & $\begin{array}{l}0.266^{\star * *} \\
(0.036)\end{array}$ & $\begin{array}{l}0.203^{\star \star *} \\
(0.032)\end{array}$ & $\begin{array}{l}0.140 * \star * \\
(0.043)\end{array}$ \\
\hline \multicolumn{9}{|l|}{ Detailed effect } \\
\hline Numerical abilities & $\begin{array}{l}0.001 \\
(0.003)\end{array}$ & $\begin{array}{l}0.001 \\
(0.004)\end{array}$ & $\begin{array}{l}0.007^{\star} \\
(0.004)\end{array}$ & $\begin{array}{l}-0.010 * * \\
(0.005)\end{array}$ & $\begin{array}{l}-0.085^{\star \star} \\
(0.037)\end{array}$ & $\begin{array}{l}-0.049 \\
(0.052)\end{array}$ & $\begin{array}{l}-0.075 \\
(0.047)\end{array}$ & $\begin{array}{l}-0.133^{\star *} \\
(0.059)\end{array}$ \\
\hline Verbal abilities & $\begin{array}{l}-0.000 \\
(0.000)\end{array}$ & $\begin{array}{l}-0.000 \\
(0.001)\end{array}$ & $\begin{array}{l}-0.000 \\
(0.000)\end{array}$ & $\begin{array}{l}-0.000 \\
(0.001)\end{array}$ & $\begin{array}{l}-0.078 \\
(0.050)\end{array}$ & $\begin{array}{l}-0.006 \\
(0.069)\end{array}$ & $\begin{array}{l}-0.128^{\star \star} \\
(0.060)\end{array}$ & $\begin{array}{l}-0.066 \\
(0.080)\end{array}$ \\
\hline Analytical abilities & $\begin{array}{l}0.001 \\
(0.001)\end{array}$ & $\begin{array}{l}0.003 \\
(0.002)\end{array}$ & $\begin{array}{l}0.001 \\
(0.001)\end{array}$ & $\begin{array}{l}-0.001 \\
(0.001)\end{array}$ & $\begin{array}{l}0.033 \\
(0.036)\end{array}$ & $\begin{array}{l}0.064 \\
(0.053)\end{array}$ & $\begin{array}{l}0.024 \\
(0.044)\end{array}$ & $\begin{array}{l}-0.008 \\
(0.057)\end{array}$ \\
\hline Locus & $\begin{array}{l}-0.000 \\
(0.000)\end{array}$ & $\begin{array}{l}0.000 \\
(0.001)\end{array}$ & $\begin{array}{l}-0.000 \\
(0.001)\end{array}$ & $\begin{array}{l}-0.000 \\
(0.000)\end{array}$ & $\begin{array}{l}0.164 \\
(0.117)\end{array}$ & $\begin{array}{l}0.184 \\
(0.173)\end{array}$ & $\begin{array}{l}0.141 \\
(0.140)\end{array}$ & $\begin{array}{l}0.448 \star \star \\
(0.186)\end{array}$ \\
\hline Age & $\begin{array}{l}0.001 \\
(0.003)\end{array}$ & $\begin{array}{l}0.002 \\
(0.003)\end{array}$ & $\begin{array}{l}0.003 \\
(0.004)\end{array}$ & $\begin{array}{l}-0.001 \\
(0.004)\end{array}$ & $\begin{array}{l}0.038 \\
(0.027)\end{array}$ & $\begin{array}{l}0.029 \\
(0.038)\end{array}$ & $\begin{array}{l}0.020 \\
(0.033)\end{array}$ & $\begin{array}{l}0.009 \\
(0.043)\end{array}$ \\
\hline Scholarship & $\begin{array}{l}0.009 * * \\
(0.004)\end{array}$ & $\begin{array}{l}0.006 \\
(0.005)\end{array}$ & $\begin{array}{l}0.007 \\
(0.004)\end{array}$ & $\begin{array}{l}0.016 \text { ** } \\
(0.007)\end{array}$ & $\begin{array}{l}0.006 \\
(0.013)\end{array}$ & $\begin{array}{l}0.001 \\
(0.017)\end{array}$ & $\begin{array}{l}-0.012 \\
(0.015)\end{array}$ & $\begin{array}{l}0.019 \\
(0.020)\end{array}$ \\
\hline Relocated & $\begin{array}{l}0.009 * \\
(0.005)\end{array}$ & $\begin{array}{l}0.002 \\
(0.007)\end{array}$ & $\begin{array}{l}0.016 * \star \\
(0.007)\end{array}$ & $\begin{array}{l}0.010 \\
(0.008)\end{array}$ & $\begin{array}{l}-0.039 * \\
(0.021)\end{array}$ & $\begin{array}{l}-0.032 \\
(0.028)\end{array}$ & $\begin{array}{l}-0.053^{\star *} \\
(0.024)\end{array}$ & $\begin{array}{l}-0.083^{\star \star \star} \\
(0.031)\end{array}$ \\
\hline Has children & $\begin{array}{l}-0.000 \\
(0.001)\end{array}$ & $\begin{array}{l}-0.000 \\
(0.002)\end{array}$ & $\begin{array}{l}0.001 \\
(0.002)\end{array}$ & $\begin{array}{l}-0.003 \\
(0.003)\end{array}$ & $\begin{array}{l}-0.024 \\
(0.021)\end{array}$ & $\begin{array}{l}0.014 \\
(0.030)\end{array}$ & $\begin{array}{l}-0.020 \\
(0.025)\end{array}$ & $\begin{array}{l}-0.025 \\
(0.033)\end{array}$ \\
\hline Married & $\begin{array}{l}-0.001 \\
(0.001)\end{array}$ & $\begin{array}{l}-0.001 \\
(0.001)\end{array}$ & $\begin{array}{l}-0.001 \\
(0.002)\end{array}$ & $\begin{array}{l}-0.002 \\
(0.002)\end{array}$ & $\begin{array}{l}-0.010 \\
(0.011)\end{array}$ & $\begin{array}{l}-0.019 \\
(0.015)\end{array}$ & $\begin{array}{l}-0.006 \\
(0.014)\end{array}$ & $\begin{array}{l}-0.002 \\
(0.020)\end{array}$ \\
\hline Prior job & $\begin{array}{l}0.006 \\
(0.005)\end{array}$ & $\begin{array}{l}0.003 \\
(0.007)\end{array}$ & $\begin{array}{l}0.005 \\
(0.006)\end{array}$ & $\begin{array}{l}0.002 \\
(0.008)\end{array}$ & $\begin{array}{l}-0.011 \\
(0.029)\end{array}$ & $\begin{array}{l}-0.031 \\
(0.043)\end{array}$ & $\begin{array}{l}-0.021 \\
(0.037)\end{array}$ & $\begin{array}{l}-0.008 \\
(0.046)\end{array}$ \\
\hline Prior internship & $\begin{array}{l}0.000 \\
(0.001)\end{array}$ & $\begin{array}{l}0.000 \\
(0.002)\end{array}$ & $\begin{array}{l}0.000 \\
(0.001)\end{array}$ & $\begin{array}{l}0.000 \\
(0.001)\end{array}$ & $\begin{array}{l}-0.016 \\
(0.030)\end{array}$ & $\begin{array}{l}-0.060 \\
(0.043)\end{array}$ & $\begin{array}{l}-0.044 \\
(0.037)\end{array}$ & $\begin{array}{l}0.049 \\
(0.049)\end{array}$ \\
\hline Performance & $\begin{array}{l}0.005 \\
(0.004)\end{array}$ & $\begin{array}{l}0.007 \\
(0.005)\end{array}$ & $\begin{array}{l}-0.002 \\
(0.004)\end{array}$ & $\begin{array}{l}0.006 \\
(0.006)\end{array}$ & $\begin{array}{l}-0.000 \\
(0.022)\end{array}$ & $\begin{array}{l}-0.016 \\
(0.030)\end{array}$ & $\begin{array}{l}0.001 \\
(0.026)\end{array}$ & $\begin{array}{l}0.039 \\
(0.037)\end{array}$ \\
\hline
\end{tabular}




\begin{tabular}{l|llll|llll}
\hline Duration & 0.003 & -0.001 & 0.002 & 0.008 & -0.042 & -0.042 & -0.154 & 0.118 \\
& $(0.002)$ & $(0.001)$ & $(0.002)$ & $(0.006)$ & $(0.092)$ & $(0.125)$ & $(0.097)$ & $(0.175)$ \\
Type of sector & -0.002 & -0.002 & -0.004 & 0.001 & 0.001 & 0.021 & -0.002 & -0.019 \\
& $(0.002)$ & $(0.003)$ & $(0.003)$ & $(0.004)$ & $(0.011)$ & $(0.014)$ & $(0.013)$ & $(0.018)$ \\
English & -0.002 & -0.009 & -0.007 & $0.018^{\star}$ & 0.017 & 0.010 & 0.032 & 0.046 \\
& $(0.006)$ & $(0.009)$ & $(0.007)$ & $(0.009)$ & $(0.033)$ & $(0.049)$ & $(0.040)$ & $(0.049)$ \\
Same course? & 0.001 & 0.003 & -0.001 & 0.001 & -0.072 & -0.090 & -0.046 & -0.101 \\
& $(0.001)$ & $(0.002)$ & $(0.002)$ & $(0.002)$ & $(0.052)$ & $(0.082)$ & $(0.062)$ & $(0.082)$ \\
Family education & 0.001 & -0.003 & 0.007 & -0.005 & -0.015 & -0.262 & -0.106 & $0.464^{\star}$ \\
& $(0.005)$ & $(0.007)$ & $(0.006)$ & $(0.008)$ & $(0.241)$ & $(0.420)$ & $(0.221)$ & $(0.275)$ \\
Primary school province & -0.000 & -0.005 & -0.003 & -0.002 & -0.283 & -0.059 & -0.311 & -0.331 \\
& $(0.006)$ & $(0.008)$ & $(0.007)$ & $(0.008)$ & $(0.242)$ & $(0.149)$ & $0.333)$ & $(0.265)$ \\
Type of primary school & -0.001 & 0.008 & -0.005 & -0.007 & -0.012 & 0.100 & -0.053 & $-0.187^{\star}$ \\
& $(0.004)$ & $(0.006)$ & $(0.005)$ & $(0.007)$ & $(0.081)$ & $(0.114)$ & $(0.101)$ & $(0.112)$ \\
University & -0.002 & 0.003 & 0.002 & -0.004 & -0.045 & 0.001 & -0.050 & -0.092 \\
& $(0.007)$ & $(0.006)$ & $(0.007)$ & $(0.009)$ & $(0.040)$ & $(0.056)$ & $(0.049)$ & $(0.068)$ \\
Study area & $0.012^{\star \star}$ & 0.001 & 0.010 & $0.019^{*}$ & -0.019 & 0.117 & 0.123 & -0.092 \\
& $(0.006)$ & $(0.007)$ & $(0.008)$ & $(0.011)$ & $(0.102)$ & $(0.150)$ & $(0.129)$ & $(0.160)$ \\
Work area & -0.006 & -0.006 & -0.001 & -0.011 & 0.082 & 0.094 & $0.375^{\star \star}$ & -0.275 \\
& $(0.007)$ & $(0.008)$ & $(0.008)$ & $(0.011)$ & $(0.159)$ & $(0.225)$ & $(0.158)$ & $(0.248)$ \\
Constant & & & & & 0.539 & 0.295 & 0.567 & 0.369 \\
& & & & & $(0.425)$ & $(0.577)$ & $(0.496)$ & $(0.572)$ \\
\hline
\end{tabular}

Note: ${ }^{*} p<0.05,{ }^{* \star} p<0.01,{ }^{* \star *} p<0.001$.

Source: authors' calculations using S2WMozUni (2018a).

Figure 4: Expected wage-gender gap distribution and decomposition into compositional (explained) and structural (unexplained) wage effects

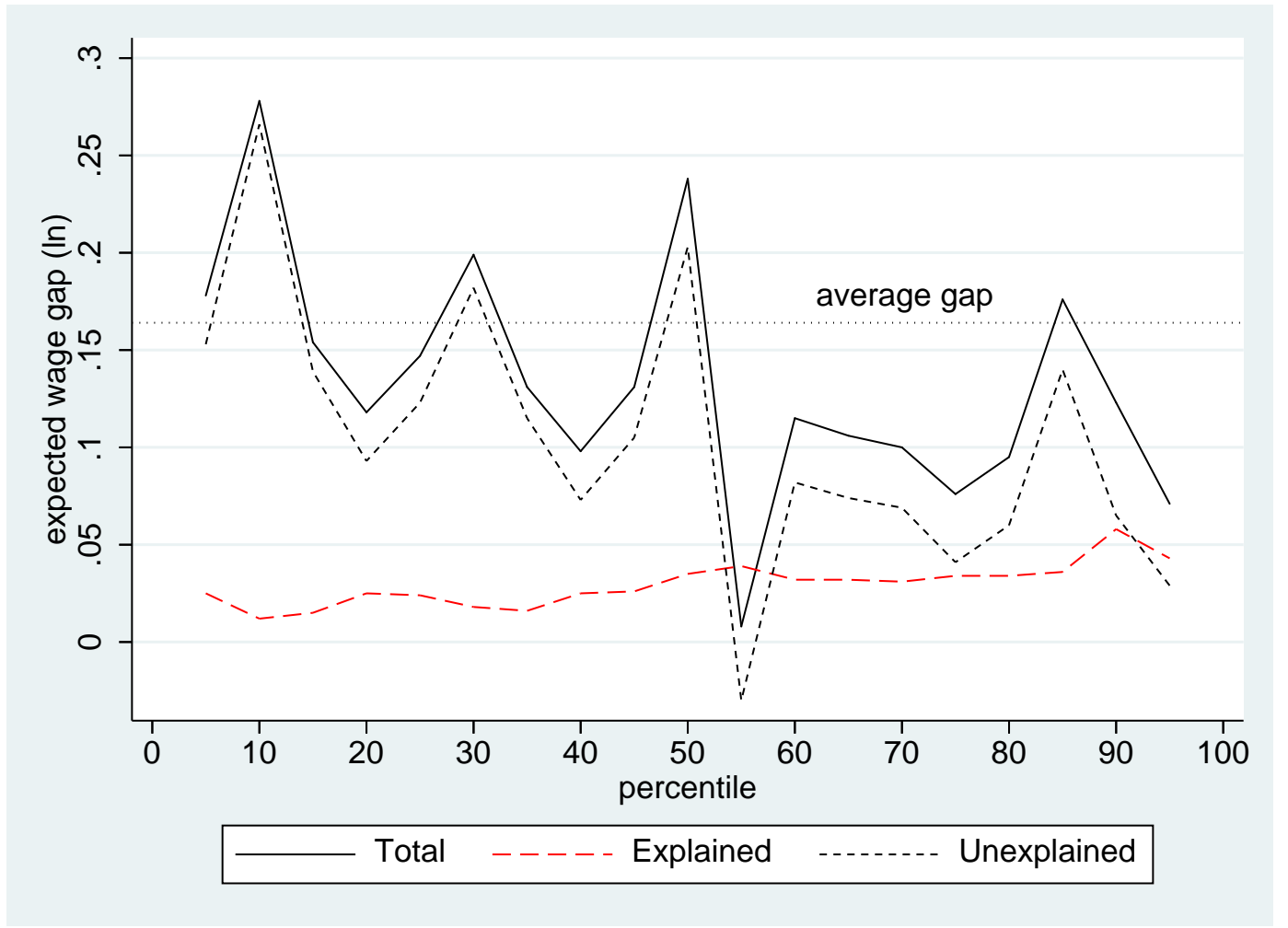

Source: authors' calculations using S2WMozUni (2018a). 
In summary, in the context of the Mozambican final-year university students, the factors suggested by the literature seem to only explain a fifth of unequal gender wage expectations, mostly at the top half of the wage distribution. Therefore, almost 80 per cent of the gender difference in the average expected salary remains unexplained even after controlling for a wide variety of personal and family characteristics, including some like family background or the results of cognitive tests that are typically omitted in studies of this kind. Similarly high results are found in the literature. Bonnard and Giret (2016), applying an Oaxaca-Ransom decomposition, found that only 29 per cent of the expected wage gap of university students in Burgundy University in France were explained by their observed characteristics, while 71 per cent could not be explained. Kiessling et al. (2019), applying an Oaxaca-Binder decomposition, found that 41.6 per cent of the expected starting wage gap and 38.2 per cent of the expected lifetime wage gap could be explained by the students' observed characteristics.

In the detailed decomposition of the unexplained term, the intercept produces the largest estimates. It is therefore difficult to identify, as this term captures the differential effect of omitted categories, as well as unobservable gender fixed effects that are uncorrelated with the other characteristics. Only the gender differential impact of numeracy and displacement to study at university are significant, with 95 and 90 per cent confidence, respectively (with positive returns and only significant for women's expected wages), but these effects are negative, which suggests that they tend to reduce the gender pay gap (which would be larger if both genders had the same expected wage structure).

While uncovering significant differences in wage expectations, our study also suggests that economic drivers alone are insufficient to explain it. In the next section, we seek to summarize what we have learned and to lay out the next steps in this inquiry.

\section{Conclusions}

Our study sought to examine the underlying causes of a consistent difference in the wage expectations of male and female final-year university students prior to their transition to the labour market. The evidence collected and presented clearly reveals that Mozambican university students anticipate wage inequality along gender lines.

To better understand these unequal expectations, we proceeded to decompose the gender difference, seeking to identify indications of gender-based segregation and stratification. We found that students' choices of study area led women to be under-represented in those expected to provide better paid jobs and over-represented in those expected to provide lower wages. This stratification appeared less stringent when we considered the preferred sectors of activity for future work, with women being under-represented in both extremes of the average expected wage distribution, while being strongly over-represented in sectors with intermediate expected wages. However, bearing in mind that within each sector, the typology of work and occupation is contingent on the skills learned, we also analysed the 'study area-sector' dyad. When both area of study and sector of activity were considered together, once again women tend to be overrepresented in lower expected wage categories.

The next step was to decompose the estimates of mean and quantile Mincer regressions to discern which factors could substantiate the unequal wage expectations. Based on the literature reviewed, covariates were sought to support probable causes for the inequality in wage expectations. Confirming the literature, various covariates, identifying what they perceive to be high productivity sectors (such as finance and tourism) or more prestigious universities, both public and private, positively correlate with the higher wage expectations of both men and women. Other covariates, such as age, sense of self-worth, the option for high-valued study areas such as engineering or 
health, appear to only be significant regressors of male wage expectations, while the average woman appears to value positively the eventual fact of having relocated to study or the prospect of working in the construction sector and, negatively, the value of a degree in the area of humanities.

However, all those covariates seem to explain up to one-fifth of total gender-based inequality in wage expectations, mainly in the right half of its distribution. Almost 80 per cent of all genderbased differences in wage expectations of university students is unexplained by the covariates suggested by the literature, even though they comprise a wide range of personal and household information. This includes information on household background and others, resulting from cognitive testing conducted with the survey participants, that are typically absent in similar studies.

Without any further evidence, one could question whether these unequal expectations were, indeed, fulfilled or whether students were wrongly presuming gender-based wage differences. In fact, Jones et al. (2020), comparing the wage estimates provided in the survey which supported this study with the later wage realizations for the same individuals, found clear evidence of a strong optimist bias of university students, which was slightly heightened in the case of men. However, the evidence presented in S2WMozUni (2019) clearly shows that women face worse entry conditions into the labour market, including taking a longer time to find a job and lower average entry wages.

This suggests that not only is there gender inequality in wages in Mozambique, but university students expect it to exist, which resonates with the literature reviewed. It is also evident that these expectations do not appear to be sufficiently explained by level of education, choice of area of study, preferred occupation, family background, or even cognitive differences, among other possible explanations suggested by the literature. It is therefore possible that the unequal expectations may stem from culturally agreed differences in the treatment of men and women in the labour market—strong suggestion of culturally established, possibly normalized, gender-based labour market discrimination.

This result also opens the possibility of a pipeline phenomenon-young female university students expecting to have the working conditions of highly educated women in the labour market. This possibility deserves further research.

If possible, further research should also explore a channel which this study could not considergender differences in how students weight different job characteristics. Heckert et al. (2002) found evidence that women and men equally rank five facets of work characteristics: family considerations, intrinsic work qualities, pleasant working conditions, pay and promotion, and job perks. They, then, suggested that women weighted family considerations and pleasant working conditions more, and pay and promotion less, than men. Zafar (2013) also found evidence that non-pecuniary outcomes weight more in female students' major choices than in male students' preferences. Zambre (2018) found evidence that women may be willing to trade off higher wages for lower wage risk. While this is a relevant research avenue, however, researchers should be cautious about possible endogeneity in these preferences, namely the possibility of women giving more weight to stronger non-pecuniary aspects and lower wage risk because they expect not to have equal access to the best pecuniary opportunities, making the risk-benefit relation not worthy.

As gender inequalities in expected wages appear to be based on non-measurable invisible factors, unequal expectations may be mitigated though an effort to increase the job market information provided to prospective candidates, including university students, and through greater transparency in recruitment processes. As employers cannot, by law, expressly offer different wages to equal candidates based on gender, more transparency in the recruitment process will allow public officials and civil society to scrutinize actual differences in recruitment practices. These can then translate into more equal wage expectations, with decisions about which course to study being increasingly based on students' skills and preferences and on labour market needs. 


\section{References}

Alonso-Borrego, C., and A. Romero-Medina (2015). 'Wage Expectations for Higher Education Students in Spain'. LABOUR 30: 1-17. https:// doi.org/10.1111/labr.12072

Bergmann, B.R. (1974). 'Occupational Segregation, Wages and Profits When Employers Discriminate by Race or Sex’. Eastern Economic Journal, 1(2): 103-10.

Bertrand, M. (2011). 'New Perspectives on Gender'. In D. Card and O. Ashenfelter (eds), Handbook of Labor Economics. Amsterdam: Elsevier. https://doi.org/10.1016/S01697218(11)02415-4

Black, G.S., and A.L. Schofield (2018). 'A Comparative Study of the Determinants of Future Plans and Expectations of Business Students'. Journal of Education for Business, 93(3): 75-87. https://doi.org/10.1080/08832323.2018.1424109

Blau, F.D., and M.A. Ferber (1991). 'Career Plans and Expectations of Young Women and Men: the Earnings Gap and Labor Force Participation'. Journal of Human Resources, 26(4): 581-607. https://doi.org/10.2307/145976

Blinder, A.S. (1973). 'Wage Discrimination: Reduced Form and Structural Estimates'. Journal of Human Resources, 8(4): 436. https://doi.org/10.2307/144855

Bonnard, C., and J.-F. Giret (2016). 'Gender Differences in French Undergraduates' Academic Plans and Wage Expectations'. Gender and Education, 28(4): 581-98. https://doi.org/10.1080/09540253.2016.1156060

Breen, R., and C. García-Peñalosa (2002). 'Bayesian Learning and Gender Segregation'. Journal of Labor Economics, 20(4): 899-922. https://doi.org/10.1086/342895

Brunello, G., C. Lucifora, and R. Winter-Ebmer, (2004). 'The Wage Expectations of European Business and Economics Students'. Journal of Human Resources, XXXIX(4): 1116-42. https://doi.org/10.3368/jhr.xxxix.4.1116

Carvajal, M.J., D. Bendana, A. Bozorgmanesh, M.A. Castillo, K. Pourmasiha, P. Rao, and J.A. Torres (2000). 'Inter-gender Differentials Between College Students' Earnings Expectations and the Experience of Recent Graduates'. Economics of Education Review, 19(3): 229-43. https://doi.org/10.1016/S0272-7757(99)00034-5

Diaz-Serrano, L., and W. Nilsson (2017). 'The Reliability of Students' Earnings Expectations'. IZA Discussion Papers 10700. Bonn: Institute of Labor Economics.

England, P., and N. Folbre (2010). 'Gender and Economic Sociology'. In N.J. Smelser and R. Swedberg (eds), The Handbook of Economic Sociology. Princeton, NJ: Princeton University Press.

Ferber, M.A., and J. A. Nelson (2009). 'The Social Construction of Economics and the Social Construction of Gender'. In M.A. Ferber and J.A. Nelson (eds), Beyond Economic Man Feminist Theory and Economics. Chicago, IL: University of Chicago Press.

Filippin, A., and A. Ichino (2005). 'Gender Wage Gap in Expectations and Realizations'. Labour Economics, 12(1): 125-45. https://doi.org/10.1016/j.labeco.2004.03.004

Firpo, S., N.M. Fortin, and T. Lemieux (2009). 'Unconditional Quantile Regressions'. Econometrica, 77(3) : 953-73. https://doi.org/10.3982/ECTA6822

Firpo, S., N. Fortin, and T. Lemieux (2018). 'Decomposing Wage Distributions Using Recentered Influence Function Regressions'. Econometrics, 28. https://doi.org/10.3390/econometrics6020028 
Fortin, N., T. Lemieux, and S. Firpo (2011). 'Decomposition Methods in Economics'. In O. Ashenfelter and D. Card (eds), Handbook of Labor Economics, edition 1, volume 4. Amsterdam: Elsevier. https://doi.org/10.1016/S0169-7218(11)00407-2

Francesconi, M., and M. Parey (2018). 'Early Gender Gaps Among University Graduates'. European Economic Review, 109, 63-82. https://doi.org/10.1016/j.euroecorev.2018.02.004

Frick, B., and M. Maihaus (2016). 'The Structure and Determinants of Expected and Actual Starting Salaries of Higher Education Students in Germany: Identical or Different?'. Education Economics, 24(4): 374-92. https://doi.org/10.1080/09645292.2015.1110115

Gradín, C. (2018). 'Occupational Gender Segregation in Post-apartheid South Africa 2018'. WIDER Working Paper 2018/53. Helsinki: UNU-WIDER. https:// doi.org/10.35188/UNU-WIDER/2018/495-7

Gradín, C. (2020a). 'Quantifying the Contribution of a Subpopulation to Inequality'. Journal of Economic Inequality, forthcoming.

Gradín, C. (2020b). 'Segregation of Women into Low-paying Occupations in the United States'. Applied Economics, 52(17): 1905-20. https:// doi.org/10.1080/00036846.2019.1682113

Gradín, C., and F. Tarp (2019). 'Investigating Growing Inequality in Mozambique'. South African Journal of Economics, 87(2): 110-38. https:// doi.org/10.1111/saje.12215

Heckert, T.M., H.E. Droste, P.J. Adams, C.M. Griffin, L.L. Roberts, M.A. Mueller, and H.A. Wallis (2002). 'Gender Differences in Anticipated Salary: Role of Salary Estimates for Others, Job Characteristics, Career Paths, and Job Inputs'. Sex Roles, 47: 139-151. https://doi.org/10.1023/A:1021095005694

Hogue, M., C.L.Z. DuBois, and L. Fox-Cardamone (2010). 'Gender Differences in Pay Expectations: The Roles of Job Intention and Self-View'. Psychology of Women Quarterly, 34(2): 215-27. https://doi.org/10.1111/j.1471-6402.2010.01563.x

Hyman, H.H. (1942). The Psychology of Status. New York, NY: Columbia University.

Jann, B. (2008). 'The Blinder-Oaxaca Decomposition for Linear Regression Models'. The Stata Journal: Promoting Communications on Statistics anad Stata, 8(4): 453-79. https://doi.org/10.1177/1536867x0800800401

Jerrim, J. (2011). 'Do Uk Higher Education Students Overestimate their Starting Salary?'. Fiscal Studies, 32(4): 483-509. https:// doi.org/10.1111/j.1475-5890.2011.00148.x

Jones, S., R. Santos, and G. Xirinda (2020). 'Misinformed, Mismatched, or Misled?'. WIDER Working Paper 2020/47. Helsinki: UNU-WIDER.

Khosrozadeh, N., J. McGinnis, O. Schnusenberg, and L.C. Jones (2013). 'Identifying Differences in Business Students' Salary Expectations'. Journal of Education for Business, 88(1): 16-25. https://doi.org/10.1080/08832323.2011.630433

Kiessling, L., P. Pinger, P. Seegers, and J. Bergerhoff (2019). 'Gender Differences in Wage Expectations: Sorting, Children, and Negotiation Styles'. IZA DP 12522. Bonn: Institute of Labor Ecomics.

Major, B., and E. Konar (1984). 'An Investigation of Sex Differences in Pay Expectations and Their Possible Causes'. Academy of Management Journal, 27(4): 777-92. https://doi.org/10.2307/255878

Manski, C.F. (1993). 'Adolescent Econometricians: How Do Youth Infer the Returns to Schooling?'. In C.T. Clotfelter and M. Rothschild (eds), Studies of Supply and Demand in Higher Education. Chicago, IL: University of Chicago Press. 
Mariani, M.D. (2008). 'A Gendered Pipeline? The Advancement of State Legislators to Congress in Five States'. Politics and Gender, 4(2): 285-308. https://doi.org/10.1017/s1743923x08000196

Menon, M.E., N. Pashourtidou, A. Polycarpou, and P. Pashardes (2012). 'Students' Expectations About Earnings and Employment and the Experience of Recent University Graduates: Evidence from Cyprus'. International Journal of Educational Development, 32(6): 805-13. https://doi.org/10.1016/j.ijedudev.2011.11.011

Mincer, J., and S. Polachek (1974). 'Family Investments in Human Capital: Earnings of Women'. Journal of Political Economy, 82(2), S76-S108. https://doi.org/10.1086/260293

Oaxaca, R. (1973). 'Male-Female Wage Differentials in Urban Labor Markets'. International Economic Review, 14(3): 693-709. https://doi.org/10.2307/2525981

Oaxaca, R.L., and M.R. Ransom (1999). 'Identification in Detailed Wage Decompositions'. Review of Economics and Statistics, 81(1): 154-57. https://doi.org/10.1162/003465399767923908

Orazem, P.F., J.D. Werbel, and J.C. McElroy (2003). 'Market Expectations, Job Search, and Gender Differences in Starting Pay'. Journal of Labor Research, 24, 307-321. https://doi.org/10.1007/BF02701795

Osikominu, A., and G. Pfeifer (2018). 'Perceived Wages and the Gender Gap in STEM Fields'. IZA DP 11321. Bonn: Institute of Labor Economics.

Polachek, S.W. (1975). 'Differences in Expected Post-School Investment as a Determinant of Market Wage Differentials'. International Economic Review, 16(2): 451-70. https://doi.org/10.2307/2525825

Polachek, S.W. (1981). 'Occupational Self-Selection: A Human Capital Approach to Sex Differences in Occupational Structure'. Review of Economics and Statistics, 63(1): 60-69. https://doi.org/10.2307/1924218

Reuben, E., M. Wiswall, and B. Zafar (2017). 'Preferences and Biases in Educational Choices and Labour Market Expectations: Shrinking the Black Box of Gender'. The Economic Journal, 127(604): 2153-86. https://doi.org/10.1111/ecoj.12350

Roy, S., and A. Kumar (2018). 'Educational Aspirations and Expectations Among Scheduled Caste Students: A Study of Uttar Pradesh, India'. Journal of Historical Archaeology \& Anthropological Sciences, 3(5): 389-694. https://doi.org/10.15406/jhaas.2018.03.00152

Ruder, A.I., and M. Van Noy (2017). 'Labor Market Expectations and Major Choice for LowIncome, First-Generation College Students: Evidence from an Information Experiment'. Available at:

https://smlr.rutgers.edu/sites/default/files/images/Research_Documents/major_choice_j une17.pdf (accessed 2 June 2020).

S2WMozUn (2018a). 'Baseline Survey on the School-to-Work Transitions of University Graduates in Mozambique - Dataset'. Copenhagen and Maputo: KU, UNU-WIDER and UEM.

S2WMozUni (2018b). 'Baseline Survey on the School-to-Work Transitions of University Graduates in Mozambique'. Copenhagen and Maputo: KU, UNU-WIDER and UEM,. Available at:

https://www.wider.unu.edu/publication/baseline-survey-school-work-transitionsuniversity-graduates-mozambique (accessed 2 June 2020).

S2WMozUni (2019). 'Survey on the School-to-Work Transitions of University Graduates in Mozambique'. Copenhagen and Maputo: KU, UNU-WIDER and UEM, Available at: 
https://www.wider.unu.edu/publication/ final-report-survey-education-employmenttransitions-university-finalists (accessed 2 June 2020).

Schweitzer, L., E. Ng, S. Lyons, and L. Kuron (2011). 'Exploring the Career Pipeline: Gender Differences in Pre-Career Expectations'. Industrial Relations, 66(3): 422-44. https://doi.org/10.7202/1006346ar

Shah, A., and M. Monahan (2018). 'Salary Expectations and Salary Realities: An Analysis of University Students in Spain and Singapore'. Journal of Organizational Psychology, 18(1). https://doi.org/10.33423/jop.v18i1.1320

Smith, H.L., and B. Powell (1990). 'Great Expectations: Variations in Income Expectations Among College Seniors'. Sociology of Education, 63(3): 194-207. https://doi.org/10.2307/2112837

Telezhkina, M., A. Maksimov, and N. Maksimova (2019). 'Students' Wage Expectations. Dynamic Analysis'. Presented at the Fourth Workshop on Computer Modelling in Decision Making (CMDM 2019), Atlantis Press. https://doi.org/10.2991/ahcs.k.191206.008

Zafar, B. (2013). 'College Major Choice and the Gender Gap'. Journal of Human Resources, 48(3): 545-95. https://doi.org/10.1353/jhr.2013.0022

Zambre, V. (2018). 'The Gender Gap in Wage Expectations: Do Young Women Trade off Higher Wages for Lower Wage Risk?'. DIW Berlin Discussion Papers 1742. Berlin: German Institute for Economic Research. https://doi.org/10.2139/ssrn.3208632 
Table A1: Expected wage gap decomposition (In), all quintiles

\begin{tabular}{|c|c|c|c|c|c|c|c|c|c|c|c|c|c|c|c|c|c|c|c|c|}
\hline & Iny & rif5 & rif10 & rif15 & rif20 & rit25 & rif30 & rif35 & rif40 & rif45 & rí50 & rit55 & rif60 & rif65 & rif70 & rif75 & rif80 & rif85 & rif9o & rif95 \\
\hline \multirow[t]{2}{*}{ Total } & $0.164^{+k \pi t}$ & $0.178^{* t *}$ & $0.278^{\text {tot }}$ & $0.154^{* t * x}$ & $0.118^{* t+x}$ & $0.147^{* t * t}$ & 0.199 the & $0.131^{* t *}$ & $0.098^{\star t+t}$ & $0.131^{\star \star \star *}$ & $0.238^{\text {tht }}$ & 0.008 & $0.115^{* * *}$ & $0.106^{t+x}$ & $0.100^{t+k x}$ & $0.076^{* *}$ & $0.095^{* * t *}$ & $0.176^{* t+x}$ & $0.123^{\text {tat }}$ & 0.071 \\
\hline & $(0.025)$ & $(0.034)$ & $(0.033)$ & $(0.031)$ & $(0.032)$ & $(0.028)$ & $(0.029)$ & $(0.027)$ & $(0.029)$ & $(0.028)$ & $(0.029)$ & $(0.028)$ & $(0.028)$ & $(0.028)$ & $(0.027)$ & $(0.031)$ & $(0.031)$ & $(0.039)$ & $(0.048)$ & $(0.048)$ \\
\hline \multirow[t]{2}{*}{ Composition effect } & $0.035^{\text {t* }}$ & 0.025 & 0.012 & 0.015 & 0.025 & 0.024 & 0.018 & 0.016 & 0.025 & 0.026 & $0.035^{*}$ & $0.039^{* *}$ & $0.032^{\star}$ & $0.032^{\star}$ & $0.031^{\star}$ & $0.034^{*}$ & $0.034^{*}$ & 0.036 & $0.058^{*}$ & 0.043 \\
\hline & $(0.016)$ & $(0.019)$ & $(0.021)$ & $(0.020)$ & $(0.020)$ & $(0.016)$ & $(0.017)$ & $(0.016)$ & $(0.018)$ & $(0.017)$ & $(0.018)$ & $(0.017)$ & $(0.017)$ & $(0.017)$ & $(0.017)$ & $(0.020)$ & $(0.020)$ & $(0.025)$ & $(0.031)$ & $(0.030)$ \\
\hline \multirow[t]{2}{*}{ Wage structure effect } & $0.129^{+2 * t}$ & $0.153^{\text {tak}}$ & $0.266^{* *+x}$ & $0.139^{\text {tate }}$ & $0.093^{\text {tat }}$ & $0.123^{\text {t*k+}}$ & $0.182^{\text {tht }}$ & $0.115^{* \star *}$ & $0.073^{* *}$ & $0.105^{\star \star *}$ & $0.203^{\text {the }}$ & -0.030 & $0.082^{\text {tht }}$ & $0.074^{\star *}$ & $0.069^{* *}$ & 0.041 & $0.060^{*}$ & $0.140^{* 2 * t}$ & 0.065 & 0.029 \\
\hline & $(0.026)$ & $(0.039)$ & $(0.036)$ & $(0.034)$ & $(0.035)$ & $(0.030)$ & $(0.031)$ & $(0.029)$ & $(0.032)$ & $(0.031)$ & $(0.032)$ & $(0.030)$ & $(0.030)$ & $(0.030)$ & $(0.029)$ & $(0.034)$ & $(0.034)$ & $(0.043)$ & $(0.053)$ & $(0.051)$ \\
\hline \multicolumn{21}{|l|}{ Composition effect } \\
\hline \multirow[t]{2}{*}{ Numerical ability } & 0.001 & 0.004 & 0.001 & 0.004 & 0.006 & $0.007^{\star *}$ & $0.007^{*}$ & $0.009^{\star *}$ & $0.009 * t$ & $0.009^{\star *}$ & $0.007^{*}$ & 0.003 & 0.002 & 0.002 & -0.001 & -0.006 & -0.006 & $-0.010^{* *}$ & $-0.010^{*}$ & -0.007 \\
\hline & $(0.003)$ & $(0.004)$ & $(0.004)$ & $(0.004)$ & $(0.004)$ & $(0.004)$ & $(0.004)$ & $(0.004)$ & $(0.004)$ & $(0.004)$ & $(0.004)$ & $(0.003)$ & $(0.003)$ & $(0.003)$ & $(0.003)$ & $(0.004)$ & $(0.004)$ & $(0.005)$ & $(0.006)$ & $(0.005)$ \\
\hline \multirow[t]{2}{*}{ Verbal ability } & -0.000 & -0.000 & -0.000 & -0.000 & -0.000 & -0.000 & 0.000 & -0.000 & -0.000 & -0.000 & -0.000 & 0.000 & 0.000 & 0.000 & -0.000 & 0.000 & 0.000 & -0.000 & -0.001 & -0.001 \\
\hline & $(0.000)$ & $(0.001)$ & $(0.001)$ & $(0.001)$ & $(0.001)$ & $(0.001)$ & $(0.000)$ & $(0.000)$ & $(0.001)$ & $(0.001)$ & $(0.000)$ & $(0.001)$ & $(0.000)$ & $(0.000)$ & $(0.000)$ & $(0.001)$ & $(0.001)$ & $(0.001)$ & $(0.002)$ & $(0.001)$ \\
\hline \multirow[t]{2}{*}{ Analytical ability } & 0.001 & 0.000 & 0.003 & 0.003 & 0.002 & 0.001 & 0.001 & 0.001 & 0.001 & 0.001 & 0.001 & -0.000 & -0.000 & -0.000 & 0.000 & -0.000 & -0.000 & -0.001 & -0.001 & -0.003 \\
\hline & $(0.001)$ & $(0.001)$ & $(0.002)$ & $(0.003)$ & $(0.002)$ & $(0.001)$ & $(0.001)$ & $(0.001)$ & $(0.001)$ & $(0.001)$ & $(0.001)$ & $(0.001)$ & $(0.001)$ & $(0.001)$ & $(0.001)$ & $(0.001)$ & $(0.001)$ & $(0.001)$ & $(0.002)$ & $(0.003)$ \\
\hline \multirow[t]{2}{*}{ Locus } & -0.000 & 0.000 & 0.000 & 0.000 & -0.000 & -0.000 & 0.000 & -0.000 & -0.000 & -0.000 & -0.000 & -0.000 & -0.000 & -0.000 & -0.000 & -0.000 & -0.000 & -0.000 & -0.000 & -0.000 \\
\hline & $(0.000)$ & $(0.001)$ & $(0.001)$ & $(0.000)$ & $(0.000)$ & $(0.000)$ & $(0.000)$ & $(0.000)$ & $(0.001)$ & $(0.001)$ & $(0.001)$ & $(0.001)$ & $(0.001)$ & $(0.001)$ & $(0.001)$ & $(0.001)$ & $(0.001)$ & $(0.000)$ & $(0.001)$ & $(0.001)$ \\
\hline \multirow[t]{2}{*}{ Age } & 0.001 & 0.001 & 0.002 & -0.000 & 0.002 & 0.001 & -0.000 & 0.001 & 0.001 & 0.001 & 0.003 & 0.001 & 0.001 & 0.001 & 0.001 & -0.001 & -0.001 & -0.001 & 0.000 & 0.000 \\
\hline & $(0.003)$ & $(0.003)$ & $(0.003)$ & $(0.003)$ & $(0.003)$ & $(0.003)$ & $(0.003)$ & $(0.003)$ & $(0.003)$ & $(0.003)$ & $(0.004)$ & $(0.003)$ & $(0.003)$ & $(0.003)$ & $(0.003)$ & $(0.003)$ & $(0.003)$ & $(0.004)$ & $(0.006)$ & $(0.005)$ \\
\hline \multirow[t]{2}{*}{ Scholarship } & $0.009^{\star *}$ & 0.004 & 0.006 & 0.006 & 0.005 & 0.004 & 0.005 & 0.003 & 0.002 & 0.002 & 0.007 & $0.009^{* *}$ & $0.010^{* *}$ & $0.010^{* *}$ & $0.009^{\star *}$ & 0.008 & 0.008 & $0.016^{* *}$ & $0.019 * *$ & $0.013^{*}$ \\
\hline & $(0.004)$ & $(0.005)$ & $(0.005)$ & $(0.005)$ & $(0.005)$ & $(0.004)$ & $(0.004)$ & $(0.004)$ & $(0.004)$ & $(0.004)$ & $(0.004)$ & $(0.004)$ & $(0.004)$ & $(0.004)$ & $(0.004)$ & $(0.005)$ & $(0.005)$ & $(0.007)$ & $(0.008)$ & $(0.007)$ \\
\hline \multirow{2}{*}{$\begin{array}{l}\text { Displaced to pursue } \\
\text { university }\end{array}$} & $0.009^{*}$ & 0.006 & 0.002 & 0.001 & 0.006 & 0.006 & 0.007 & 0.008 & 0.007 & 0.007 & $0.016^{* *}$ & $0.014^{* \star}$ & $0.015^{\text {t* }}$ & $0.015^{* *}$ & $0.013^{\text {t* }}$ & 0.012 & 0.012 & 0.010 & $0.018^{*}$ & 0.006 \\
\hline & $(0.005)$ & $(0.006)$ & $(0.007)$ & $(0.007)$ & $(0.007)$ & $(0.006)$ & $(0.006)$ & $(0.006)$ & $(0.007)$ & $(0.006)$ & $(0.007)$ & $(0.006)$ & $(0.006)$ & $(0.006)$ & $(0.006)$ & $(0.007)$ & $(0.007)$ & $(0.008)$ & $(0.010)$ & $(0.010)$ \\
\hline \multirow[t]{2}{*}{ Has children } & -0.000 & -0.000 & -0.000 & -0.001 & 0.001 & 0.001 & 0.001 & 0.001 & 0.001 & 0.001 & 0.001 & 0.002 & 0.002 & 0.002 & -0.000 & -0.002 & -0.002 & -0.003 & -0.002 & -0.002 \\
\hline & $(0.001)$ & $(0.002)$ & $(0.002)$ & $(0.002)$ & $(0.002)$ & $(0.002)$ & $(0.002)$ & $(0.002)$ & $(0.002)$ & $(0.002)$ & $(0.002)$ & $(0.002)$ & $(0.002)$ & $(0.002)$ & $(0.001)$ & $(0.002)$ & $(0.002)$ & $(0.003)$ & $(0.003)$ & $(0.003)$ \\
\hline \multirow[t]{2}{*}{ Married } & -0.001 & -0.001 & -0.001 & -0.001 & -0.003 & -0.002 & -0.001 & -0.001 & -0.001 & -0.001 & -0.001 & -0.002 & -0.002 & -0.002 & -0.001 & -0.001 & -0.001 & -0.002 & -0.001 & 0.000 \\
\hline & $(0.001)$ & $(0.002)$ & $(0.001)$ & $(0.001)$ & $(0.002)$ & $(0.002)$ & $(0.001)$ & $(0.001)$ & $(0.001)$ & $(0.001)$ & $(0.002)$ & $(0.002)$ & $(0.002)$ & $(0.002)$ & $(0.001)$ & $(0.002)$ & $(0.002)$ & $(0.002)$ & $(0.002)$ & $(0.002)$ \\
\hline \multirow[t]{2}{*}{ Worked or working } & 0.006 & 0.003 & 0.003 & 0.007 & $0.012^{\star}$ & $0.010^{\star}$ & 0.008 & 0.007 & 0.004 & 0.005 & 0.005 & $0.010^{*}$ & $0.010^{*}$ & $0.010^{*}$ & 0.008 & 0.006 & 0.006 & 0.002 & -0.000 & -0.001 \\
\hline & $(0.005)$ & $(0.007)$ & $(0.007)$ & $(0.007)$ & $(0.007)$ & $(0.006)$ & $(0.006)$ & $(0.006)$ & $(0.006)$ & $(0.006)$ & $(0.006)$ & $(0.006)$ & $(0.006)$ & $(0.006)$ & $(0.005)$ & $(0.006)$ & $(0.006)$ & $(0.008)$ & $(0.009)$ & $(0.009)$ \\
\hline \multirow{2}{*}{ Had an internship } & 0.000 & 0.000 & 0.000 & 0.000 & 0.000 & 0.000 & 0.000 & 0.000 & 0.000 & 0.000 & 0.000 & 0.000 & 0.000 & 0.000 & 0.000 & 0.000 & 0.000 & 0.000 & 0.000 & 0.000 \\
\hline & $(0.001)$ & $(0.001)$ & $(0.002)$ & $(0.002)$ & $(0.002)$ & $(0.001)$ & $(0.001)$ & $(0.001)$ & $(0.001)$ & $(0.001)$ & $(0.001)$ & $(0.002)$ & $(0.001)$ & $(0.001)$ & $(0.001)$ & $(0.001)$ & $(0.001)$ & $(0.001)$ & $(0.001)$ & $(0.001)$ \\
\hline
\end{tabular}




\begin{tabular}{|c|c|c|c|c|c|c|c|c|c|c|c|c|c|c|c|c|c|c|c|c|}
\hline & Iny & rif5 & rif10 & rif15 & rif20 & rit25 & rif30 & rif35 & rif40 & rif45 & rif50 & rit55 & rif60 & rif65 & rif70 & rif75 & rif80 & rif85 & rif9o & rif95 \\
\hline \multirow{2}{*}{$\begin{array}{l}\text { Self-assessed } \\
\text { performance }\end{array}$} & 0.005 & 0.002 & 0.007 & 0.005 & 0.007 & 0.006 & 0.005 & 0.005 & -0.001 & -0.001 & -0.002 & -0.000 & -0.001 & -0.001 & 0.001 & 0.003 & 0.003 & 0.006 & 0.005 & 0.005 \\
\hline & $(0.004)$ & $(0.005)$ & $(0.005)$ & $(0.004)$ & $(0.005)$ & $(0.004)$ & $(0.004)$ & $(0.004)$ & $(0.004)$ & $(0.004)$ & $(0.004)$ & $(0.004)$ & $(0.004)$ & $(0.004)$ & $(0.004)$ & $(0.005)$ & $(0.005)$ & $(0.006)$ & $(0.006)$ & $(0.006)$ \\
\hline \multirow[t]{2}{*}{ Duration } & 0.003 & -0.001 & -0.001 & -0.001 & 0.000 & 0.000 & 0.001 & 0.001 & 0.001 & 0.001 & 0.002 & 0.003 & 0.003 & 0.003 & 0.004 & 0.006 & 0.006 & 0.008 & 0.009 & 0.011 \\
\hline & $(0.002)$ & $(0.001)$ & $(0.001)$ & $(0.001)$ & $(0.001)$ & $(0.001)$ & $(0.001)$ & $(0.001)$ & $(0.001)$ & $(0.001)$ & $(0.002)$ & $(0.002)$ & $(0.002)$ & $(0.002)$ & $(0.003)$ & $(0.004)$ & $(0.004)$ & $(0.006)$ & $(0.006)$ & $(0.007)$ \\
\hline \multirow{2}{*}{$\begin{array}{l}\text { Type of secondary } \\
\text { school. }\end{array}$} & -0.002 & 0.001 & -0.002 & -0.003 & -0.003 & -0.004 & $-0.005^{\star}$ & $-0.004^{*}$ & -0.003 & -0.003 & -0.004 & -0.003 & -0.003 & -0.003 & -0.004 & -0.001 & -0.001 & 0.001 & 0.003 & 0.001 \\
\hline & $(0.002)$ & $(0.003)$ & $(0.003)$ & $(0.003)$ & $(0.003)$ & $(0.003)$ & $(0.003)$ & $(0.003)$ & $(0.003)$ & $(0.003)$ & $(0.003)$ & $(0.003)$ & $(0.003)$ & $(0.003)$ & $(0.003)$ & $(0.003)$ & $(0.003)$ & $(0.004)$ & $(0.005)$ & $(0.005)$ \\
\hline \multirow[t]{2}{*}{ English proficiency } & -0.002 & -0.002 & -0.009 & -0.005 & -0.010 & -0.009 & -0.010 & -0.010 & -0.005 & -0.004 & -0.007 & -0.007 & -0.008 & -0.008 & -0.006 & 0.001 & 0.001 & $0.018^{*}$ & $0.022^{\star \star}$ & 0.016 \\
\hline & $(0.006)$ & $(0.008)$ & $(0.009)$ & $(0.008)$ & $(0.008)$ & $(0.007)$ & $(0.007)$ & $(0.006)$ & $(0.007)$ & $(0.007)$ & $(0.007)$ & $(0.007)$ & $(0.007)$ & $(0.007)$ & $(0.006)$ & $(0.008)$ & $(0.008)$ & $(0.009)$ & $(0.011)$ & $(0.010)$ \\
\hline \multirow{2}{*}{$\begin{array}{l}\text { Would choose same } \\
\text { course? }\end{array}$} & 0.001 & 0.002 & 0.003 & 0.002 & 0.001 & 0.000 & -0.001 & -0.001 & -0.001 & -0.001 & -0.001 & -0.001 & -0.001 & -0.001 & -0.001 & 0.001 & 0.001 & 0.001 & 0.000 & -0.000 \\
\hline & $(0.001)$ & $(0.002)$ & $(0.002)$ & $(0.002)$ & $(0.002)$ & $(0.001)$ & $(0.001)$ & $(0.001)$ & $(0.002)$ & $(0.001)$ & $(0.002)$ & $(0.001)$ & $(0.001)$ & $(0.001)$ & $(0.001)$ & $(0.002)$ & $(0.002)$ & $(0.002)$ & $(0.002)$ & $(0.002)$ \\
\hline \multirow{2}{*}{$\begin{array}{l}\begin{array}{l}\text { Household Education } \\
\text { level }\end{array} \\
\end{array}$} & 0.001 & 0.000 & -0.003 & 0.002 & -0.001 & 0.001 & 0.000 & -0.001 & 0.006 & 0.006 & 0.007 & 0.005 & 0.002 & 0.002 & 0.001 & -0.001 & -0.001 & -0.005 & -0.012 & -0.010 \\
\hline & $(0.005)$ & $(0.006)$ & $(0.007)$ & $(0.006)$ & $(0.006)$ & $(0.005)$ & $(0.005)$ & $(0.005)$ & $(0.006)$ & $(0.005)$ & $(0.006)$ & $(0.005)$ & $(0.005)$ & $(0.005)$ & $(0.005)$ & $(0.006)$ & $(0.006)$ & $(0.008)$ & $(0.009)$ & $(0.010)$ \\
\hline \multirow{2}{*}{$\begin{array}{l}\text { Primary education } \\
\text { prov. }\end{array}$} & -0.000 & -0.010 & -0.005 & -0.003 & -0.004 & -0.003 & -0.004 & -0.004 & -0.004 & -0.004 & -0.003 & -0.001 & -0.001 & -0.001 & 0.004 & 0.009 & 0.009 & -0.002 & 0.008 & 0.010 \\
\hline & $(0.006)$ & $(0.007)$ & $(0.008)$ & $(0.007)$ & $(0.008)$ & $(0.006)$ & $(0.007)$ & $(0.006)$ & $(0.007)$ & $(0.007)$ & $(0.007)$ & $(0.007)$ & $(0.006)$ & $(0.006)$ & $(0.006)$ & $(0.008)$ & $(0.008)$ & $(0.008)$ & $(0.011)$ & $(0.011)$ \\
\hline \multirow{2}{*}{$\begin{array}{l}\text { Type primary } \\
\text { education }\end{array}$} & -0.001 & $0.012^{\star \star}$ & 0.008 & 0.003 & 0.005 & 0.000 & -0.002 & -0.001 & -0.001 & -0.000 & -0.005 & -0.006 & -0.008 & -0.008 & -0.005 & -0.000 & -0.000 & -0.007 & $-0.016^{*}$ & -0.008 \\
\hline & $(0.004)$ & $(0.006)$ & $(0.006)$ & $(0.006)$ & $(0.006)$ & $(0.005)$ & $(0.005)$ & $(0.005)$ & $(0.005)$ & $(0.005)$ & $(0.005)$ & $(0.005)$ & $(0.005)$ & $(0.005)$ & $(0.005)$ & $(0.006)$ & $(0.006)$ & $(0.007)$ & $(0.008)$ & $(0.008)$ \\
\hline \multirow[t]{2}{*}{ University } & -0.002 & 0.005 & 0.003 & 0.004 & 0.006 & 0.005 & 0.005 & 0.004 & 0.002 & 0.002 & 0.002 & -0.002 & -0.002 & -0.002 & -0.001 & -0.004 & -0.004 & -0.004 & -0.008 & -0.018 \\
\hline & $(0.007)$ & $(0.006)$ & $(0.006)$ & $(0.006)$ & $(0.007)$ & $(0.007)$ & $(0.007)$ & $(0.007)$ & $(0.007)$ & $(0.007)$ & $(0.007)$ & $(0.007)$ & $(0.007)$ & $(0.007)$ & $(0.007)$ & $(0.008)$ & $(0.008)$ & $(0.009)$ & $(0.011)$ & $(0.012)$ \\
\hline \multirow[t]{2}{*}{ Study area } & $0.012^{\star \star}$ & -0.000 & 0.001 & 0.003 & 0.005 & 0.005 & 0.008 & 0.006 & 0.010 & 0.010 & 0.010 & $0.014^{*}$ & $0.013^{*}$ & $0.013^{*}$ & $0.016^{\star *}$ & $0.018^{\star *}$ & $0.018^{* *}$ & $0.019^{*}$ & $0.030^{* *}$ & $0.035^{\text {tat }}$ \\
\hline & $(0.006)$ & $(0.007)$ & $(0.007)$ & $(0.007)$ & $(0.008)$ & $(0.007)$ & $(0.007)$ & $(0.007)$ & $(0.007)$ & $(0.007)$ & $(0.008)$ & $(0.007)$ & $(0.007)$ & $(0.007)$ & $(0.007)$ & $(0.009)$ & $(0.009)$ & $(0.011)$ & $(0.013)$ & $(0.011)$ \\
\hline \multirow{2}{*}{$\begin{array}{l}\text { Expected work } \\
\text { sector }\end{array}$} & -0.006 & -0.001 & -0.006 & -0.009 & -0.011 & -0.007 & -0.006 & -0.005 & -0.004 & -0.004 & -0.001 & -0.001 & -0.001 & -0.001 & -0.006 & $-0.014^{*}$ & $-0.014^{*}$ & -0.011 & -0.006 & -0.003 \\
\hline & $(0.007)$ & $(0.006)$ & $(0.008)$ & $(0.007)$ & $(0.008)$ & $(0.007)$ & $(0.007)$ & $(0.007)$ & $(0.008)$ & $(0.007)$ & $(0.008)$ & $(0.007)$ & $(0.007)$ & $(0.007)$ & $(0.007)$ & $(0.008)$ & $(0.008)$ & $(0.011)$ & $(0.012)$ & $(0.012)$ \\
\hline \multirow{3}{*}{$\begin{array}{l}\text { Wage structure } \\
\text { effect } \\
\text { Numerical ability }\end{array}$} & & & & & & & & & & & & & & & & & & & & \\
\hline & $-0.085^{* *}$ & -0.020 & -0.049 & $-0.101^{\star \star}$ & $-0.085^{*}$ & -0.069 & -0.067 & $-0.098^{\text {t* }}$ & -0.099 t* & $-0.098^{t *}$ & -0.075 & $-0.084^{*}$ & $-0.088^{* *}$ & $-0.088^{\star *}$ & -0.032 & $-0.095^{\star}$ & $-0.095^{\star}$ & $-0.133^{\text {** }}$ & -0.094 & -0.103 \\
\hline & $(0.037)$ & $(0.053)$ & $(0.052)$ & $(0.049)$ & $(0.049)$ & $(0.043)$ & $(0.045)$ & $(0.042)$ & $(0.045)$ & $(0.044)$ & $(0.047)$ & $(0.044)$ & $(0.044)$ & $(0.044)$ & $(0.042)$ & $(0.049)$ & $(0.049)$ & $(0.059)$ & $(0.070)$ & $(0.067)$ \\
\hline \multirow[t]{2}{*}{ Verbal ability } & -0.078 & 0.010 & -0.006 & -0.026 & -0.019 & -0.030 & -0.075 & -0.058 & -0.083 & -0.084 & $-0.128^{* *}$ & $-0.110^{*}$ & $-0.123^{\text {t* }}$ & $-0.123^{* \star}$ & $-0.113^{\text {t* }}$ & -0.084 & -0.084 & -0.066 & -0.074 & -0.099 \\
\hline & $(0.050)$ & $(0.080)$ & $(0.069)$ & $(0.066)$ & $(0.068)$ & $(0.059)$ & $(0.060)$ & $(0.056)$ & $(0.060)$ & $(0.058)$ & $(0.060)$ & $(0.059)$ & $(0.057)$ & $(0.057)$ & $(0.055)$ & $(0.065)$ & $(0.065)$ & $(0.080)$ & $(0.093)$ & $(0.096)$ \\
\hline \multirow[t]{2}{*}{ Analytical ability } & 0.033 & -0.018 & 0.064 & 0.067 & 0.030 & 0.009 & 0.021 & 0.040 & 0.048 & 0.044 & 0.024 & 0.012 & 0.013 & 0.013 & -0.002 & -0.022 & -0.022 & -0.008 & 0.028 & 0.093 \\
\hline & $(0.036)$ & $(0.050)$ & (0.053) & $(0.049)$ & $(0.050)$ & $(0.044)$ & $(0.044)$ & $(0.041)$ & $(0.043)$ & $(0.042)$ & $(0.044)$ & $(0.043)$ & $(0.042)$ & $(0.042)$ & $(0.040)$ & $(0.046)$ & $(0.046)$ & $(0.057)$ & $(0.068)$ & $(0.072)$ \\
\hline \multirow[t]{2}{*}{ Locus } & 0.164 & 0.121 & 0.184 & -0.020 & 0.016 & -0.001 & 0.072 & -0.009 & 0.084 & 0.081 & 0.141 & 0.174 & 0.199 & 0.199 & $0.241^{*}$ & 0.211 & 0.211 & $0.448^{* \star}$ & $0.476^{\text {** }}$ & 0.385 \\
\hline & $(0.117)$ & $(0.151)$ & (0.173) & $(0.159)$ & $(0.157)$ & $(0.137)$ & $(0.140)$ & $(0.129)$ & $(0.139)$ & $(0.135)$ & $(0.140)$ & $(0.136)$ & $(0.132)$ & $(0.132)$ & $(0.128)$ & $(0.148)$ & (0.148) & $(0.186)$ & $(0.226)$ & $(0.240)$ \\
\hline \multirow[t]{2}{*}{ Age } & 0.038 & 0.008 & 0.029 & $0.063^{*}$ & $0.093^{\text {*t }}$ & $0.073^{* *}$ & 0.052 & $0.055^{*}$ & $0.061^{*}$ & $0.058^{*}$ & 0.020 & 0.002 & 0.003 & 0.003 & 0.027 & 0.005 & 0.005 & 0.009 & $0.082^{\star}$ & 0.055 \\
\hline & $(0.027)$ & $(0.038)$ & $(0.038)$ & $(0.036)$ & $(0.038)$ & $(0.034)$ & $(0.034)$ & $(0.031)$ & $(0.034)$ & $(0.033)$ & $(0.033)$ & $(0.032)$ & $(0.031)$ & $(0.031)$ & $(0.029)$ & $(0.034)$ & $(0.034)$ & $(0.043)$ & $(0.049)$ & $(0.051)$ \\
\hline \multirow[t]{2}{*}{ Scholarship } & 0.006 & -0.003 & 0.001 & 0.005 & 0.004 & 0.001 & -0.000 & 0.010 & 0.009 & 0.009 & -0.012 & 0.000 & 0.002 & 0.002 & 0.007 & 0.004 & 0.004 & 0.019 & 0.028 & 0.039 \\
\hline & $(0.013)$ & $(0.017)$ & $(0.017)$ & $(0.016)$ & $(0.016)$ & $(0.014)$ & $(0.014)$ & $(0.014)$ & $(0.014)$ & $(0.014)$ & $(0.015)$ & $(0.014)$ & $(0.014)$ & $(0.014)$ & $(0.014)$ & $(0.016)$ & $(0.016)$ & $(0.020)$ & $(0.025)$ & $(0.024)$ \\
\hline
\end{tabular}




\begin{tabular}{|c|c|c|c|c|c|c|c|c|c|c|c|c|c|c|c|c|c|c|c|c|}
\hline \multirow{2}{*}{$\begin{array}{l}\text { Displaced to } \\
\text { pursue university }\end{array}$} & $-0.039^{*}$ & -0.021 & -0.032 & -0.021 & -0.004 & -0.007 & -0.010 & -0.017 & -0.020 & -0.020 & $-0.053^{\text {t* }}$ & $-0.060^{* \star}$ & $-0.060^{2+x+x}$ & $-0.060^{* t+x}$ & $-0.048^{* *}$ & $-0.052^{\text {** }}$ & $-0.052^{* *}$ & $-0.083^{* t+k}$ & $-0.085 * *$ & $-0.062^{\star}$ \\
\hline & $(0.021)$ & $(0.026)$ & $(0.028)$ & $(0.026)$ & $(0.026)$ & $(0.024)$ & $(0.024)$ & $(0.022)$ & $(0.024)$ & $(0.023)$ & $(0.024)$ & $(0.023)$ & $(0.023)$ & $(0.023)$ & $(0.022)$ & $(0.025)$ & $(0.025)$ & $(0.031)$ & $(0.039)$ & $(0.037)$ \\
\hline \multirow[t]{2}{*}{ Has children } & -0.024 & 0.024 & 0.014 & -0.006 & -0.039 & -0.032 & -0.026 & -0.022 & -0.019 & -0.018 & -0.020 & -0.025 & -0.024 & -0.024 & $-0.053^{* *}$ & -0.032 & -0.032 & -0.025 & -0.061 & $-0.074^{* *}$ \\
\hline & $(0.021)$ & $(0.035)$ & $(0.030)$ & $(0.027)$ & $(0.029)$ & $(0.025)$ & $(0.026)$ & $(0.024)$ & $(0.025)$ & $(0.025)$ & $(0.025)$ & $(0.025)$ & $(0.025)$ & $(0.025)$ & $(0.023)$ & $(0.027)$ & $(0.027)$ & $(0.033)$ & $(0.038)$ & $(0.036)$ \\
\hline \multirow[t]{2}{*}{ Married } & -0.010 & -0.021 & -0.019 & $-0.025^{*}$ & -0.009 & -0.014 & -0.006 & -0.003 & -0.000 & -0.001 & -0.006 & 0.012 & 0.016 & 0.016 & $0.024^{*}$ & 0.019 & 0.019 & -0.002 & -0.019 & -0.009 \\
\hline & $(0.011)$ & $(0.019)$ & $(0.015)$ & $(0.014)$ & $(0.014)$ & $(0.012)$ & $(0.013)$ & $(0.012)$ & $(0.014)$ & $(0.013)$ & $(0.014)$ & $(0.014)$ & $(0.013)$ & $(0.013)$ & $(0.013)$ & $(0.016)$ & $(0.016)$ & $(0.020)$ & $(0.022)$ & $(0.022)$ \\
\hline \multirow[t]{2}{*}{ Worked or working } & -0.011 & -0.028 & -0.031 & -0.060 & -0.028 & -0.039 & -0.016 & -0.012 & -0.026 & -0.024 & -0.021 & -0.003 & -0.006 & -0.006 & 0.003 & -0.013 & -0.013 & -0.008 & 0.020 & 0.058 \\
\hline & $(0.029)$ & $(0.040)$ & $(0.043)$ & $(0.041)$ & $(0.042)$ & $(0.036)$ & $(0.036)$ & $(0.034)$ & $(0.037)$ & $(0.036)$ & $(0.037)$ & $(0.035)$ & $(0.034)$ & $(0.034)$ & $(0.033)$ & $(0.038)$ & $(0.038)$ & $(0.046)$ & $(0.055)$ & $(0.054)$ \\
\hline \multirow[t]{2}{*}{ Had an Internship } & -0.016 & $-0.119^{*+1+x}$ & -0.060 & -0.028 & -0.048 & -0.045 & -0.033 & -0.032 & -0.037 & -0.037 & -0.044 & -0.020 & -0.036 & -0.036 & -0.018 & -0.015 & -0.015 & 0.049 & $0.139^{* *}$ & $0.104^{*}$ \\
\hline & $(0.030)$ & $(0.038)$ & $(0.043)$ & $(0.038)$ & $(0.040)$ & $(0.034)$ & $(0.036)$ & $(0.033)$ & $(0.036)$ & $(0.035)$ & $(0.037)$ & $(0.035)$ & $(0.034)$ & $(0.034)$ & $(0.033)$ & $(0.038)$ & $(0.038)$ & $(0.049)$ & $(0.061)$ & $(0.058)$ \\
\hline \multirow{2}{*}{$\begin{array}{l}\text { Self-assessed } \\
\text { performance }\end{array}$} & -0.000 & $-0.065^{* *}$ & -0.016 & 0.006 & 0.020 & 0.016 & 0.014 & 0.025 & -0.003 & -0.002 & 0.001 & 0.021 & 0.017 & 0.017 & 0.004 & 0.023 & 0.023 & 0.039 & -0.013 & -0.019 \\
\hline & $(0.022)$ & $(0.031)$ & $(0.030)$ & $(0.028)$ & $(0.029)$ & $(0.026)$ & $(0.026)$ & $(0.024)$ & $(0.026)$ & $(0.026)$ & $(0.026)$ & $(0.026)$ & $(0.026)$ & $(0.026)$ & $(0.025)$ & $(0.030)$ & $(0.030)$ & $(0.037)$ & $(0.045)$ & $(0.045)$ \\
\hline \multirow[t]{2}{*}{ Duration } & -0.042 & -0.063 & -0.042 & -0.090 & -0.022 & -0.036 & -0.089 & -0.075 & -0.061 & -0.067 & -0.154 & -0.041 & -0.055 & -0.055 & $-0.177^{\text {*t* }}$ & -0.002 & -0.002 & 0.118 & -0.168 & -0.002 \\
\hline & $(0.092)$ & $(0.124)$ & $(0.125)$ & (0.119) & $(0.116)$ & $(0.098)$ & $(0.098)$ & $(0.092)$ & $(0.098)$ & $(0.094)$ & $(0.097)$ & $(0.096)$ & $(0.092)$ & $(0.092)$ & $(0.090)$ & $(0.117)$ & $(0.117)$ & $(0.175)$ & $(0.224)$ & $(0.254)$ \\
\hline \multirow{2}{*}{$\begin{array}{l}\text { Type of secondary } \\
\text { school. }\end{array}$} & 0.001 & 0.008 & 0.021 & 0.019 & 0.021 & $0.023^{*}$ & 0.018 & $0.019^{*}$ & 0.011 & 0.011 & -0.002 & -0.008 & -0.008 & -0.008 & -0.010 & -0.024 & -0.024 & -0.019 & -0.021 & -0.019 \\
\hline & $(0.011)$ & $(0.013)$ & $(0.014)$ & $(0.012)$ & $(0.014)$ & $(0.012)$ & $(0.012)$ & $(0.011)$ & $(0.013)$ & $(0.012)$ & $(0.013)$ & $(0.013)$ & $(0.013)$ & $(0.013)$ & $(0.012)$ & $(0.015)$ & $(0.015)$ & $(0.018)$ & $(0.022)$ & $(0.024)$ \\
\hline \multirow[t]{2}{*}{ English proficiency } & 0.017 & 0.009 & 0.010 & -0.024 & -0.057 & -0.057 & -0.041 & -0.035 & 0.001 & 0.006 & 0.032 & 0.035 & 0.023 & 0.023 & 0.022 & 0.068 & 0.068 & 0.046 & 0.076 & $0.145^{\text {tom }}$ \\
\hline & $(0.033)$ & $(0.052)$ & $(0.049)$ & $(0.044)$ & $(0.043)$ & $(0.038)$ & $(0.038)$ & $(0.035)$ & $(0.040)$ & $(0.039)$ & $(0.040)$ & $(0.038)$ & $(0.037)$ & $(0.037)$ & $(0.036)$ & $(0.042)$ & $(0.042)$ & $(0.049)$ & $(0.058)$ & $(0.056)$ \\
\hline \multirow{2}{*}{$\begin{array}{l}\text { Would choose } \\
\text { same course? }\end{array}$} & -0.072 & -0.048 & -0.090 & -0.110 & -0.045 & -0.022 & -0.059 & -0.046 & -0.037 & -0.039 & -0.046 & -0.042 & -0.045 & -0.045 & -0.061 & $-0.145^{\text {** }}$ & $-0.145^{* *}$ & -0.101 & $-0.187^{*}$ & -0.141 \\
\hline & $(0.052)$ & $(0.089)$ & $(0.082)$ & $(0.072)$ & $(0.068)$ & $(0.057)$ & $(0.059)$ & $(0.055)$ & $(0.061)$ & $(0.059)$ & $(0.062)$ & $(0.060)$ & $(0.058)$ & $(0.058)$ & $(0.057)$ & $(0.064)$ & $(0.064)$ & $(0.082)$ & $(0.100)$ & $(0.102)$ \\
\hline \multirow{2}{*}{$\begin{array}{l}\text { Household } \\
\text { education level }\end{array}$} & -0.015 & -0.481 & -0.262 & 0.073 & 0.038 & 0.058 & 0.076 & 0.020 & -0.180 & -0.175 & -0.106 & 0.011 & 0.168 & 0.168 & 0.238 & 0.255 & 0.255 & $0.464^{*}$ & 0.500 & 0.574 \\
\hline & $(0.241)$ & $(0.406)$ & $(0.420)$ & $(0.243)$ & $(0.241)$ & $(0.226)$ & $(0.214)$ & $(0.214)$ & $(0.221)$ & $(0.218)$ & $(0.221)$ & $(0.213)$ & $(0.205)$ & $(0.205)$ & $(0.211)$ & $(0.223)$ & $(0.223)$ & $(0.275)$ & $(0.407)$ & $(0.474)$ \\
\hline \multirow{2}{*}{$\begin{array}{l}\text { Primary education } \\
\text { prov. }\end{array}$} & -0.283 & 0.087 & -0.059 & -0.584 & -0.537 & -0.486 & -0.459 & -0.393 & -0.334 & -0.332 & -0.311 & -0.447 & -0.351 & -0.351 & -0.133 & -0.353 & -0.353 & -0.331 & -0.505 & -0.175 \\
\hline & $(0.242)$ & $(0.141)$ & $(0.149)$ & $(0.385)$ & $(0.393)$ & $(0.391)$ & $(0.345)$ & $(0.301)$ & $(0.324)$ & $(0.319)$ & $(0.333)$ & $(0.321)$ & $(0.312)$ & $(0.312)$ & $(0.329)$ & $(0.356)$ & $(0.356)$ & $(0.265)$ & $(0.315)$ & $(0.257)$ \\
\hline \multirow{2}{*}{$\begin{array}{l}\text { Type primary } \\
\text { education }\end{array}$} & -0.012 & 0.044 & 0.100 & 0.028 & -0.022 & 0.039 & 0.046 & 0.035 & 0.029 & 0.023 & -0.053 & -0.044 & -0.036 & -0.036 & 0.042 & -0.047 & -0.047 & $-0.187^{\star}$ & -0.166 & -0.150 \\
\hline & $(0.081)$ & $(0.117)$ & $(0.114)$ & $(0.107)$ & $(0.107)$ & $(0.100)$ & $(0.101)$ & $(0.093)$ & $(0.100)$ & $(0.098)$ & $(0.101)$ & $(0.098)$ & $(0.096)$ & $(0.096)$ & $(0.093)$ & $(0.103)$ & $(0.103)$ & $(0.112)$ & $(0.135)$ & (0.139) \\
\hline \multirow[t]{2}{*}{ University } & -0.045 & 0.056 & 0.001 & -0.024 & -0.057 & -0.034 & -0.041 & -0.041 & $-0.079^{*}$ & -0.069 & -0.050 & -0.055 & -0.053 & -0.053 & -0.071 & $-0.106^{*}$ & $-0.106^{*}$ & -0.092 & -0.053 & -0.082 \\
\hline & $(0.040)$ & $(0.057)$ & $(0.056)$ & $(0.051)$ & $(0.054)$ & $(0.049)$ & $(0.048)$ & $(0.045)$ & $(0.048)$ & $(0.047)$ & $(0.049)$ & $(0.049)$ & $(0.048)$ & $(0.048)$ & $(0.046)$ & $(0.055)$ & $(0.055)$ & $(0.068)$ & $(0.086)$ & $(0.086)$ \\
\hline \multirow[t]{2}{*}{ Study area } & -0.019 & 0.106 & 0.117 & -0.010 & -0.157 & -0.084 & -0.024 & 0.020 & 0.078 & 0.080 & 0.123 & 0.029 & -0.000 & -0.000 & -0.057 & -0.094 & -0.094 & -0.092 & -0.246 & -0.055 \\
\hline & $(0.102)$ & $(0.168)$ & $(0.150)$ & $(0.155)$ & $(0.148)$ & $(0.129)$ & $(0.127)$ & $(0.118)$ & $(0.131)$ & $(0.126)$ & $(0.129)$ & $(0.123)$ & $(0.120)$ & $(0.120)$ & $(0.116)$ & $(0.138)$ & $(0.138)$ & $(0.160)$ & $(0.166)$ & $(0.144)$ \\
\hline \multirow{2}{*}{$\begin{array}{l}\text { Expected work } \\
\text { sector }\end{array}$} & 0.082 & -0.146 & 0.094 & 0.167 & 0.159 & 0.135 & 0.156 & 0.183 & $0.355^{* *}$ & $0.335^{* *}$ & $0.375^{* *}$ & 0.197 & 0.214 & 0.214 & 0.109 & -0.090 & -0.090 & -0.275 & -0.249 & -0.132 \\
\hline & $(0.159)$ & $(0.156)$ & $(0.225)$ & $(0.212)$ & $(0.200)$ & $(0.165)$ & $(0.157)$ & $(0.147)$ & $(0.160)$ & (0.155) & $(0.158)$ & $(0.160)$ & (0.149) & $(0.149)$ & $(0.142)$ & $(0.181)$ & $(0.181)$ & $(0.248)$ & $(0.297)$ & $(0.354)$ \\
\hline \multirow[t]{2}{*}{ Intercept } & 0.539 & 0.711 & 0.295 & 0.843 & 0.838 & 0.725 & 0.675 & 0.549 & 0.375 & 0.422 & 0.567 & 0.416 & 0.314 & 0.305 & 0.128 & 0.631 & 0.650 & 0.369 & 0.658 & -0.301 \\
\hline & $(0.425)$ & $(0.558)$ & $(0.577)$ & $(0.561)$ & $(0.569)$ & $(0.542)$ & $(0.501)$ & $(0.462)$ & $(0.487)$ & $(0.478)$ & $(0.496)$ & $(0.484)$ & $(0.470)$ & $(0.470)$ & $(0.474)$ & $(0.525)$ & $(0.525)$ & $(0.572)$ & $(0.744)$ & $(0.819)$ \\
\hline
\end{tabular}

Note: ${ }^{*} p<0.05,{ }^{* *} p<0.01,{ }^{* \star *} p<0.001$.

Source: authors' calculations using S2WMozUni (2018a). 